\title{
ParB spreading on DNA requires cytidine triphosphate in vitro
}

\author{
Adam S. B. Jalal ${ }^{1}$, Ngat T. Tran ${ }^{1}$, and Tung B. K. Le ${ }^{1^{*}}$ \\ 1Department of Molecular Microbiology \\ John Innes Centre, Norwich, NR4 7UH, United Kingdom \\ *For correspondence: tung.le@jic.ac.uk
}

\begin{abstract}
In all living organisms, it is essential to transmit genetic information faithfully to the next generation. The SMC-ParAB-parS system is widely employed for chromosome segregation in bacteria. A DNA-binding protein ParB nucleates on parS sites and must associate with neighboring DNA, a process known as spreading, to enable efficient chromosome segregation. Despite its importance, how the initial few ParB molecules nucleating at parS sites recruit hundreds of further ParB to spread is not fully understood. Here, we reconstitute a parS-dependent ParB spreading event using purified proteins from Caulobacter crescentus and show that CTP is required for spreading. We further show that ParB spreading requires a closed DNA substrate, and a DNA-binding transcriptional regulator can act as a roadblock to attenuate spreading unidirectionally in vitro. Our biochemical reconstitutions recapitulate many observed in vivo properties of ParB and opens up avenues to investigate the interactions between ParB-parS with ParA and SMC.
\end{abstract}




\section{INTRODUCTION}

Faithful chromosome segregation is essential in all domains of life if daughter cells are each to inherit the full set of genetic information. The SMC-ParAB-parS complex is widely employed for chromosome segregation in bacteria ${ }^{1-13}$. The centromere parS is the first DNA locus to be segregated following chromosome replication ${ }^{8,9,14,15}$. ParB specifically nucleates on parS before spreading outwards to the flanking DNA and bridges/cages DNA together to form a nucleoprotein network in vivo ${ }^{16-23}$. This nucleoprotein complex recruits SMC to disentangle and organize replicated DNA ${ }^{3,11,13,24,25}$. ParB-parS also interacts with an ATPase ParA to power the segregation of replicated chromosomes $26-30$. Engineered strains harboring a nucleation-competent but spreading-defective mutant of parB are either unviable ${ }^{10}$ or have elevated number of anucleate cells 4,7,8,15,31-34. Despite the importance of spreading for proper chromosome segregation, the mechanism by which a few parS-bound ParB can recruit hundreds more ParB molecules to the vicinity of parS to assemble a high molecular-weight nucleoprotein complex is not fully understood.

Since the first report in $1995^{35}$, ParB spreading has been observed in vivo by chromatin immunoprecipitation in multiple bacterial species ${ }^{12,15-17,19,36}$. The nucleation of ParB on parS has also been demonstrated in vitro 4,10,16,17,20,37-39, however parS-dependent ParB spreading has resisted biochemical reconstitution 17-19,40,41. Unsuccessful attempts to reconstitute spreading in vitro suggests that additional factors might be missing. Recently, works by Soh et al (2019) and Osorio-Valeriano et al (2019) on Bacillus subtilis and Myxococcus xanthus ParB, respectively, showed that ParB binds and hydrolyzes cytidine triphosphate (CTP) to cytidine diphosphate (CDP), and that CTP modulates the binding affinity of ParB to parS ${ }^{42,43}$. A co-crystal structure of Bacillus ParB with CDP and that of a Myxococcus ParB-like protein (PadC) with CTP showed CTP binding promotes a new dimerization interface between N-terminal domains of ParB subunits ${ }^{42,43}$. Crucially, Soh et al (2019) showed by single-molecule imaging and cross-linking assays that Bacillus ParB, in the presence of CTP, forms a self-loading protein clamp at parS and slides away to spread to neighboring DNA ${ }^{43}$. While reproducing a key result from Easter and Gober (2002) that showed Caulobacter crescentus ParA-ATP dissociated pre-bound ParB from parS ${ }^{44}$, we found that CTP could also modulate the nucleation of Caulobacter ParB on parS. Personal communication with Stephan Gruber and the recent work by Osorio-Valeriano et al (2019) and Soh et al (2019) encouraged us to take steps further to investigate the role of CTP for ParB spreading in Caulobacter crescentus.

Here, we reconstitute a parS-dependent ParB spreading on DNA in real-time, using a label-free purified protein from Caulobacter crescentus. Consistent with pioneering works by Soh et al (2019) and Osorio-Valeriano et al (2019), we confirm that CTP regulates ParB-DNA interaction. We further provide evidence that the accumulation of Caulobacter ParB requires a closed DNA substrate, and that a DNA-binding transcription factor, TetR, can act as a roadblock to attenuate ParB accumulation unidirectionally in vitro. Our real-time and label-free reconstitution has successfully recapitulated many well-known aspects of ParB behaviors in vivo and might open up avenues to investigate further the roles of the ParB-parS nucleoprotein complex in ensuring faithful chromosome segregation.

\section{RESULTS}

\section{CTP reduces the nucleation of Caulobacter ParB on parS}

Easter and Gober (2002) reported that ATP-bound Caulobacter ParA dissociated ParB from parS ${ }^{44}$, however the authors did not control for the effect of ATP alone on ParB-parS binding. NTPs are highly negatively charged and could have affected protein-DNA interactions by binding nonspecifically to the often positively charged DNA-binding domain. To determine if ATP or other NTP alone affects ParB-parS interaction, we attached a linear 20-bp biotinylated parS DNA to a streptavidin-coated probe to measure the bio-layer interference (BLI) (Figure 1A). BLI assay monitors wavelength shifts (responses) resulting from changes in the optical thickness of the probe surface during association or dissociation of the analyte (see Materials and Methods). We 
bioRxiv preprint doi: https://doi.org/10.1101/2019.12.11.865972; this version posted February 20, 2020. The copyright holder for this preprint (which was not certified by peer review) is the author/funder. All rights reserved. No reuse allowed without permission.

monitored in real-time interactions between immobilized parS DNA and purified Caulobacter ParB or a premix of ParB + NTP (Figure 1B). Consistent with previous reports ${ }^{12,45}$, Caulobacter ParB bound site-specifically to parS but not to non-cognate DNA (Figure 1-figure supplement 1). In the presence of ATP, GTP, or UTP, we observed a small reduction in ParB-parS binding at steady state regardless of whether $\mathrm{Mg}^{2+}$ was included in binding buffer or not (Figure 1B and Figure 1figure supplement 2), suggesting that Caulobacter ParB is slightly sensitive to highly negatively charged compounds or to counter-ions $\left(\mathrm{Na}^{+}\right)$in NTP solutions. However, we noted that CTP had a pronounced effect on ParB-parS interaction, specifically in the presence of $\mathrm{Mg}^{2+}$ (Figure $1 \mathrm{~B}$ and Figure1-figure supplement 2). An increasing concentration of CTP (but not CMP or CDP) gradually reduced the binding of ParB to parS (Figure 1-figure supplement 3). In contrast, neither CTP nor other NTPs affected the binding of another protein-DNA pair, for example, the well-characterized TetR-tetO interaction ${ }^{46}$ (Figure $1 \mathrm{C}$ ). On closer inspection, we noted that ParB + CTP slowly dissociated from parS even before the probe was returned to a protein-free buffer (a gradual downward slope between $30^{\text {th }}$ and $150^{\text {th }} \mathrm{sec}$, Figure 1B), suggesting that CTP facilitated ParB removal from a 20-bp parS DNA. To investigate further, we monitored the dissociation rates of prebound CTP-free ParB-parS complexes after probes were returned to a protein-free buffer with or without CTP, we found ParB dissociating seven times faster in buffer with CTP than in buffer only solution (Figure 1D). Given the short length of a 20-bp parS DNA duplex that has only sufficient room for nucleation, our results suggest that CTP might decrease ParB nucleation on parS or liberates pre-bound ParB from parS site.

\section{CTP facilitates ParB accumulation on a closed DNA substrate}

Next, we investigated the effect of CTP on ParB-DNA interaction by employing a longer 169-bp parS-containing DNA fragment that has been labeled at both 5 ' ends with biotin (Figure 2A). Immobilizing a dual biotin-labeled DNA on a streptavidin-coated BLI probe created a DNA substrate where both ends were blocked (a closed DNA) ${ }^{47}$ (Figure 2-figure supplement 1 ). We monitored the interactions between immobilized DNA and purified Caulobacter ParB in the presence or absence of NTP. In the absence of NTP, we observed the usual nucleation event on parS with $1 \mu \mathrm{M}$ ParB protein (Figure $2 \mathrm{~A}$ ). We noted that the BLI signal was not as high as with a 20-bp parS probe (Figure 2A) due to a less efficient immobilization of a longer DNA fragment on the BLI probe. Premixing ATP, GTP, or UTP with ParB did not change the sensorgrams markedly (Figure 2A). However, the addition of CTP significantly increased the response by $\sim 12$ fold (Figure $2 \mathrm{~A}$ and Figure 2-figure supplement $2 \mathrm{~A}$ ), suggesting that more ParB associated with a 169-bp parS probe at steady state than by nucleation at parS alone. We observed that DNA-bound ParB was salt sensitive and dissociated readily to the solution when the BLI probe was returned to a low-salt protein-free buffer without CTP (Figure 2A, dissociation phase). However, the dissociation of prebound ParB-CTP from DNA was slowed down by fivefold if the probe was returned to a buffer supplemented with CTP (Figure 2-figure supplement $2 \mathrm{~B}$ ). The effect on the BLI response was not seen if $\mathrm{Mg}^{2+}$ was omitted (Figure 2-figure supplement $2 \mathrm{C}$ ), neither did we observe an equivalent increase in response when a 169-bp dual biotin-labeled DNA containing a scrambled parS was employed instead (Figure 2A). Furthermore, we observed that a nucleation-competent but spreading-defective Caulobacter ParB (R104A) ${ }^{12}$ mutant did not respond to the addition of CTP to the same extent as ParB (WT) (Figure 2B). Our results suggest that CTP is required for the increase in parS-dependent ParB accumulation in vitro. Lastly, we performed BLI experiments for eight additional chromosomal ParB proteins from a diverse set of bacterial species and consistently observed the specific effect of CTP on enhancing ParB association with a closed DNA in vitro (Figure 2-figure supplement 3 ). It is most likely that ParB-CTP interaction with DNA is conserved among ParB orthologs.

To independently verify the BLI data, we performed an in vitro pull-down of purified His-tagged Caulobacter ParB (Figure 2C). Streptavidin-coated paramagnetic beads were incubated with 2.8$\mathrm{kb}$ dual biotin-labeled DNA fragments containing either parS or scrambled parS sites. Again, a dual biotin-labeled DNA formed a closed substrate on the surface of the beads. DNA-coated beads were incubated with purified Caulobacter ParB either in the presence or absence of NTP before 
bioRxiv preprint doi: https://doi.org/10.1101/2019.12.11.865972; this version posted February 20, 2020. The copyright holder for this preprint (which was not certified by peer review) is the author/funder. All rights reserved. No reuse allowed without permission.

being pulled down magnetically. Pulled-down ParB was released from beads and their protein level was analyzed by an $\alpha-\mathrm{His}_{6}$ immunoblot (Figure $2 \mathrm{C}$ ). We found $\sim 13-15$ fold more pulled-down ParB when CTP was included (Figure $2 \mathrm{C}$ ). No enrichment was observed when scrambled parS-coated beads were used, confirming that the extensive in vitro association of ParB with DNA is dependent on pars (Figure $2 \mathrm{C}$ ). Also, consistent with the BLI experiments, no further enrichment of ParB was seen when ATP, GTP or UTP was included (Figure 2C). Furthermore, a ParB (R104A) variant was not enriched in our pull-down assay regardless of whether CTP was present or not (Figure 2C). Altogether, our results suggest that a parS-dependent accumulation of ParB on a closed DNA substrate requires CTP.

\section{A closed DNA substrate is required for an increased ParB association with DNA}

Next, we investigated whether a DNA substrate with a free end (an open DNA) can also support ParB accumulation in vitro. The 169-bp dual biotin-labeled DNA was designed with unique BamHI and EcoRI recognition sites flanking the parS site (Figure 3A). To generate an open end on DNA, we immerged the DNA-coated probes in buffers contained either BamHI or EcoRI (Figure 3A-C and Figure 3-figure supplement 1). Before restriction enzyme digestion, we again observed an enhanced ParB association with a closed DNA substrate in the presence of CTP (Figure 3A). After digestion by either BamHI or EcoRI, the inclusion of CTP had no effect on the BLI response, indicating that ParB did not accumulate on an open DNA substrate in vitro (Figure 3B-C). Our conclusion was further supported by results from an experiment in which we added $B a m H I$ after ParB + CTP and a closed DNA substrate were preincubated together for $120 \mathrm{sec}$ (Figure 3-figure supplement 2). Here, in the presence of $B a m H I$, ParB binding to DNA reduced gradually over 30 min, while it was unaffected if heat-inactivated BamHI was employed instead (Figure 3-figure supplement 2). Lastly, consistent with BLI experiments, our pull-down assay also showed that ParB-CTP failed to accumulate when a 2.8-kb dual biotin-labeled DNA was linearized by HindIII digestion (Figure 3D).

Next, we wondered if a tight protein-DNA binding could cap the open end of DNA, thereby mimicking a closed DNA substrate and restoring ParB accumulation. To investigate this possibility, we constructed a 170-bp dual biotin-labeled DNA fragment that contains a single parS site, a tetO operator, and flanking restriction enzyme recognition sites for EcoRI and BamHI (Figure 4A). With this closed DNA substrate, we observed an enhanced ParB association with DNA in the presence of CTP (Figure 4A). Again, we generated a free DNA end via restriction enzyme digestion. Consistent with previous experiments with a restricted 169-bp DNA probe, the addition of ParB + CTP had no effect on the BLI response (Figure 4B). However, it can be partially rescued by incubating a BamHI-restricted DNA probe with a premix of ParB + CTP + TetR (Figure 4B). We reason that TetR binding at tetO capped the open DNA end, essentially generated a closed DNA substrate. Our conclusion was further supported by results from an experiment in which a premix of ParB + CTP + TetR was tested against an EcoRI-restricted DNA instead (Figure 4C). Here, we did not observe an enhanced association of ParB with DNA even when TetR was included, most likely because of a persistent open DNA end that could not be blocked by TetR-tetO binding (Figure 4C). Finally, we observed that the TetR could attenuate ParB-CTP accumulation on a closed DNA substrate (magenta line vs. orange line, Figure 4A). This blocking effect is specific to TetR-tetO binding since the addition of anhydrotetracycline (ahTc), a negative effector of TetR ${ }^{46}$, allowed ParB-CTP to regain its accumulation on DNA (Figure 4-figure supplement 1). Overall, the ability of a DNA-bound TetR to act as a roadblock in vitro is consistent with previous ChIP-seq data that showed DNA-binding proteins or RNA polymerases could block or attenuate ParB spreading unidirectionally in vivo ${ }^{16,17,20,36}$.

\section{parS DNA increases the CTP binding and hydrolysis rate of Caulobacter ParB}

Recently, Myxococcus and Bacillus ParB were shown to bind and hydrolyze CTP ${ }^{42,43}$. Our in vitro results so far also hint at CTP binding directly to Caulobacter ParB. By employing a membranespotting assay (DRaCALA), we showed that Caulobacter ParB binds to radiolabeled CTP in the presence of parS DNA (Figure 5A). An excess of unlabeled CTP, but no other NTPs, could 
bioRxiv preprint doi: https://doi.org/10.1101/2019.12.11.865972; this version posted February 20, 2020. The copyright holder for this preprint (which was not certified by peer review) is the author/funder. All rights reserved. No reuse allowed without permission.

compete with radioactive CTP for binding to Caulobacter ParB (Figure 5B), suggesting that Caulobacter ParB does not bind other NTPs. The CTP binding of ParB was reduced when a noncognate DNA site (NBS) ${ }^{48}$ was used instead of parS (Figure 5A). We also failed to detect CTP binding in our DRaCALA assay or by isothermal titration calorimetry when DNA was omitted. Nevertheless, we robustly detected CTP hydrolysis to CDP and inorganic phosphate when Caulobacter ParB and CTP were included, albeit at a very low rate of $\sim 0.4$ CTP molecules per ParB per hour (Figure 5C). A background level of inorganic phosphate was observed when Caulobacter ParB was incubated with ATP, GTP, or UTP (Figure 5C). Crucially, the addition of a 22-bp parS DNA, but not a non-cognate 22-bp NBS DNA, increased CTP turnover rate sevenfold to $\sim 3$ CTP molecules per ParB per hour (Figure 5C). Lastly, the CTP hydrolysis was reduced to the background in the nucleation-competent but spreading-defective ParB (R104A) variant (Figure 5C). Altogether, our data suggest that parS DNA stimulates Caulobacter ParB to bind and hydrolyze CTP.

\section{ParB accumulation on DNA is unstable in the presence of a non-hydrolyzable analog CTPYS}

Next, we investigated the role of CTP hydrolysis by following ParB-parS interaction in the presence of a non-hydrolyzable analog CTPYS (Figure 6A and Figure 6-figure supplement 1). ParB was preincubated with CTP or CTPYS for 1 to 60 min before binding to a 169-bp closed parS DNA substrate (Figure 6A). We observed that Caulobacter ParB could accumulate on DNA in the presence of CTPYS, but in contrast to when CTP was employed, a longer preincubation time between ParB and CTPYS gradually reduced ParB accumulation on DNA (Figure 6A). Our results suggest the possibility that CTPYS, in the absence of parS DNA, converts apo-ParB in solution to a nucleation-incompetent form over time. Our observation is reminiscent of a time-course experiment in which CTPYS efficiently promoted the engagement between $\mathrm{N}$-terminal domains of Bacillus $\mathrm{ParB}$ in the absence of parS DNA ${ }^{43}$. The engagement of $\mathrm{N}$-terminal domains was shown to convert Bacillus ParB from an open to a closed protein clamp ${ }^{43}$. If not already bound on DNA, the closed form of ParB presumably cannot nucleate/load onto parS due to its now inaccessible DNAbinding domain ${ }^{43}$. We wondered if CTPYS also catalyzed the $\mathrm{N}$-domain engagement in Caulobacter ParB in the absence of parS DNA. To investigate this possibility, we employed sitespecific cross-linking of a purified Caulobacter ParB (Q35C C297S) variant by a sulfhydryl-tosulfhydryl crosslinker bismaleimidoethane (BMOE) (Figure 6B). A lone cysteine residue on the native ParB was first mutated to serine to create a cysteine-less ParB (C297S) variant, then a glutamine to cysteine mutation was engineered at position 35 at the $\mathrm{N}$-terminal domain to create ParB (Q35C C297S). Both ParB (C297S) and ParB (Q35C C297S) were competent at spreading in the presence of CTP (Figure 6-figure supplement 2A). The cross-linking of ParB (Q35C C297S) was also enhanced by CTP and CTPYS but not by other NTPs, consistent with the specific role of CTP in ParB spreading (Figure 6-figure supplement 2B). We performed a time-course cross-linking of ParB (Q35C C297S) + CTP or CTPyS in the absence of parS DNA (Figure 6B). As shown in Figure 6B, CTPYS was twice as efficient as CTP in promoting the cross-linked form between Nterminal domains of Caulobacter ParB. The rapid increase in the nucleation-incompetent closed form of Caulobacter ParB might explain the overall reduction in accumulation overtime when ParB was preincubated with CTPYS (Figure 6A).

To further investigate the effect of CTPYS on ParB spreading on a longer time scale, we extended the association phase between 169-bp parS DNA and a freshly prepared premix of ParB + CTP or CTPYS from $120 \mathrm{sec}$ to $60 \mathrm{~min}$ (Figure 6C). In the presence of CTP, the reaction reached steady state after $120 \mathrm{sec}$ and remained stable for the duration of the association phase (Figure 6C). However, in the presence of CTPYS, ParB accumulation rapidly reached the maximal level after $200 \mathrm{sec}$, then declined slowly over $60 \mathrm{~min}$. We suggest that DNA-bound ParB-CTPYS complexes gradually dissociated from DNA into solution (possibly via a transient clamp opening or CTPYS leaving its weak binding pocket rather than by hydrolysis) but were not replenished by a new cycle of nucleation-spreading-dissociation because over time most ParB-CTPYS in solution was in a nucleation-incompetent closed form. Taken together, we suggest that CTP hydrolysis is not 
bioRxiv preprint doi: https://doi.org/10.1101/2019.12.11.865972; this version posted February 20, 2020. The copyright holder for this preprint (which was not certified by peer review) is the author/funder. All rights reserved. No reuse allowed without permission.

required for parS-bound ParB to escape the nucleation site to spread, but possibly contributes to maintaining the stability of spreading by recycling ParB.

\section{DISCUSSION}

In this work, we report that a small molecule (CTP) is required to enable Caulobacter ParB proteins (as well as eight other chromosomal ParB proteins, Figure 2-figure supplement 3) to spread in vitro. Recently, Soh et al (2019) observed that F-plasmid and P1-plasmid ParB proteins also bind and hydrolyze CTP ${ }^{43}$. Hence, it is most likely that the effect of CTP on ParB spreading is universal among plasmid and chromosomal ParB orthologs. A classical mutant whose arginine-rich patch $\left(G^{101}\right.$ ERRxR) has been mutated to alanine e.g. ParB (R104A) ${ }^{8}$ was not responsive to CTP, suggesting that CTP is bound to the N-terminal domain of Caulobacter ParB. Indeed, Soh et al (2019) reported a co-crystal structure that showed CDP binding to the arginine-rich patch at the Nterminal domain of Bacillus ParB (CTP was hydrolyzed to CDP during crystallization) ${ }^{43}$. OsorioValeriano et al (2019) also showed a similar binding pocket of CTP at the N-terminal domain of Myxococcus ParB by hydrogen-deuterium exchange mass spectrometry ${ }^{42}$. Intriguingly, a cocrystal structure of a Helicobacter pylori ParB-parS complex, together with the in vitro magnetictweezer and single-molecule TIRF microscopy-based experiments with Bacillus ParB showed that the $\mathrm{N}$-terminal domain can oligomerize to bridge DNA together without the need of an additional ligand ${ }^{18,19,37,40}$. There might be two different modes of action of ParB on DNA: one for bridging DNA together (that does not require CTP) and another for the lateral spreading of ParB on DNA (that requires CTP). Investigating the relative contribution of these two different modes of action to chromosome segregation in vivo is an important challenge for the future.

The requirement of a DNA substrate with blocked ends for ParB accumulation in vitro is suggestive of a lateral ParB diffusion along the DNA i.e. ParB can escape by running off a free DNA end (Figure 7). Inside cells, the spreading and bridging/caging of ParB have been inferred from the compact foci of fluorescently labeled ParB ${ }^{4,15,20,49-53}$, presumably resulting from the concentration of fluorescent signal to a defined location in the cytoplasm. Nucleation-competent but spreadingdefective ParB mutants formed no or very diffusive foci in vivo ${ }^{19,54}$. Recently, it has been observed that an artificially engineered double-strand break $\sim 8 \mathrm{~kb}$ away from parS did not cause a dissolution of ParB foci in Caulobacter cells ${ }^{55}$. This result seemingly contradicted our findings that Caulobacter ParB spreading in vitro requires a closed DNA. However, we reason that the abundant DNA-bound transcription factors and RNA polymerases in vivo act as roadblocks to minimize ParB runoff. This barricading effect has been recapitulated in our experiments with TetR, a tight DNAbinding transcriptional regulator (Figure 4).

Our results so far suggest three distinct stages of Caulobacter ParB-DNA interactions in vitro:

Stage 1: ParB nucleates on parS (Figure 7A). Results from experiments in Figure 1 indicate that CTP modulates ParB nucleation on a parS site. Soh et al (2019) reported that CTP-bound ParB could form a closed protein clamp even in the absence of parS DNA, albeit not energetically favorable ${ }^{43}$. The DNA-binding domain of a closed ParB clamp would be inaccessible to DNA, especially to a closed DNA substrate. It might be that only apo-ParB or a transiently formed CDPbound ParB (from CTP hydrolysis) are able to nucleate on parS (Figure 7A). Supporting this interpretation, preincubation of Caulobacter ParB with a non-hydrolyzable analog CTPYS promoted efficiently the cross-linked form of ParB and subsequently reduced ParB nucleation and spreading on DNA (Figure 6). Initially, we were surprised by a weak CTP binding of Bacillus, Caulobacter, and Myxococcus ParBs ${ }^{42,43}$, however, this might be advantageous for the cells as a fraction of intracellular apo-ParB will remain to nucleate on parS.

Stage 2: Nucleated ParB escapes from parS (Figure 7B-C). We showed that Caulobacter ParBparS complex binds CTP, and this facilitates ParB dissociation from parS (Figure 1D). It was reported that the DNA-binding domain in Bacillus ParB-CDP co-crystal structure is incompatible with pars binding ${ }^{43}$ and this might enable ParB to escape from a high-affinity nucleation site to non-specific flanking DNA. Our observation of a low BLI response with an open DNA (Figure 3 and 
bioRxiv preprint doi: https://doi.org/10.1101/2019.12.11.865972; this version posted February 20, 2020. The copyright holder for this preprint (which was not certified by peer review) is the author/funder. All rights reserved. No reuse allowed without permission.

Figure 4) implies that ParB proteins dissociate off the free end well before the next ParB escapes from the parS nucleation site. We suggest that the transition from a parS-bound ParB to a spreading ParB might be the rate-limiting step.

Stage 3: ParB spreads or diffuses to non-specific DNA flanking parS. Our observation that Caulobacter ParB did not accumulate on an open DNA suggests that Caulobacter ParB diffuses laterally along the DNA. Similarly, cross-linking experiments on Bacillus ParB ${ }^{43}$ proposed that the ParB-CTP complex forms a sliding clamp that moves along the DNA ${ }^{43}$. From our experiments with CTPYS (Figure 6) and consistent with Soh et al (2019), we suggest that the diffusive Caulobacter ParB along the DNA is CTP bound. The low CTP hydrolysis rate of Caulobacter ParB ( 3 CTP molecules per ParB per hour) while ParB spreading could be observed by BLI within minutes also lends support to the interpretation that the diffusive spreading form of Caulobacter ParB is most likely CTP-bound (Figure 7B-C). For Bacillus and Caulobacter ParB, CTP hydrolysis is not required for ParB to escape from the nucleation site ${ }^{43}$. Caulobacter ParB could still spread on a DNA when incubated with a non-hydrolyzable CTPYS (Figure 6), even though spreading, at least in vitro, was less stable over time in comparison to when CTP was employed (Figure 6C). As suggested for Bacillus ParB ${ }^{43}$ and supported by our results with Caulobacter ParB, CTP hydrolysis might contribute to ParB recycling instead. It is possible that ParB recycling in vivo is achieved via several routes: (i) CTP dissociation from its weak binding pocket, (ii) CTP hydrolysis, (iii) a possible enhanced CTP dissociation/hydrolysis via collisions with DNA-bound roadblocks, or (iv) a transient clamp opening even when ParB is CTP bound. Additional work is required to investigate the dynamics of ParB clamp opening/closing, and whether both CTP molecules on opposite subunits of a ParB dimer are concertedly hydrolyzed/dissociated for ParB to escape from the chromosome or a heterodimer state of ParB with a single CTP bound exists in vivo.

\section{FINAL PERSPECTIVES}

In this work, we showed the enhancing effect of CTP on Caulobacter ParB accumulation on DNA and further demonstrated that ParB spreading requires a closed DNA substrate and that a DNAbinding transcriptional regulator can act as a roadblock to attenuate spreading unidirectionally in vitro. Our real-time and label-free reconstitution of ParB spreading has successfully recapitulated many well-known aspects of ParB behaviors and is consistent with pioneering works by Soh et al (2019) and Osorio-Valeriano et al (2019). Beyond the biological significance of the findings, our label-free approaches to biochemical reconstitution obviate the often time-consuming and challenging task of site-specifically labeling proteins with fluorophores/chemical crosslinkers without affecting the function of proteins. Here, we have demonstrated the medium-throughput capability of our methodology by investigating the effect of CTP on the spreading of eight additional chromosomal ParB proteins. The ease and medium-throughput manner of our methodology is likely to facilitate future works by the community. Important areas of research in the future are to investigate (i) the effect of ParB-CTP spreading on the supercoiling state of the DNA and vice versa, and (ii) how ParA and SMC interact with ParB-CTP in vivo to organize and faithfully segregate replicated chromosomes to each daughter cell.

\section{ACKNOWLEDGEMENTS}

This study was funded by the Royal Society University Research Fellowship (UF140053), BBSRC grant (BB/P018165/1 and BBS/E/J/000PR9791), and Royal Society Research Grant (RG150448) (to T.B.K.L). We thank Dr. Wilma Ross (Department of Bacteriology, University of Wisconsin, Madison) for advice on DRaCALA assays, and Dr. Clare Stevenson (Biophysical Platform, John Innes Centre) for assistance in biophysical techniques. We thank Dr. César López Pastrana (Faculty of Physics, Technical University of Munich) for valuable feedback on the manuscript, and Dr. Stephan Gruber and Dr. Martin Thanbichler for sharing reagents and data. 
MATERIALS AND METHODS

\begin{tabular}{|c|c|c|c|c|}
\hline \multicolumn{5}{|c|}{ Key Resources Table } \\
\hline $\begin{array}{l}\text { Reagent } \\
\text { type } \\
\text { (species) or } \\
\text { resource }\end{array}$ & Designation & $\begin{array}{l}\text { Source or } \\
\text { reference }\end{array}$ & Identifiers & $\begin{array}{l}\text { Additional } \\
\text { information }\end{array}$ \\
\hline $\begin{array}{l}\text { strain, strain } \\
\text { background } \\
\text { (Escherichia } \\
\text { coli) }\end{array}$ & Rosetta (DE3) & Merck & Cat\# 70954 & $\begin{array}{l}\text { Electro- } \\
\text { competent } \\
\text { cells }\end{array}$ \\
\hline $\begin{array}{l}\text { recombinant } \\
\text { DNA reagent }\end{array}$ & $\begin{array}{l}\text { See supplementary } \\
\text { file } 1\end{array}$ & This paper & $\begin{array}{l}\text { See supplementary } \\
\text { file } 1\end{array}$ & \\
\hline $\begin{array}{l}\text { sequence- } \\
\text { based } \\
\text { reagent }\end{array}$ & $\begin{array}{l}\text { See supplementary } \\
\text { file } 1\end{array}$ & This paper & $\begin{array}{l}\text { See supplementary } \\
\text { file } 1\end{array}$ & \\
\hline antibody & $\begin{array}{l}\text { Anti-6xHis tag } \\
\text { antibody (HRP) } \\
\text { (Rabbit polyclonal) }\end{array}$ & Abcam & Cat\# ab1187 & $\begin{array}{l}\text { Western blot } \\
(1: 5,000)\end{array}$ \\
\hline $\begin{array}{l}\text { commercial } \\
\text { assay or kit }\end{array}$ & $\begin{array}{l}\text { EnzChek } \\
\text { Phosphate Assay } \\
\text { Kit }\end{array}$ & ThermoFisher & Cat\# E6646 & \\
\hline $\begin{array}{l}\text { commercial } \\
\text { assay or kit }\end{array}$ & $\begin{array}{l}\text { Gibson Assembly } \\
\text { Master Mix }\end{array}$ & NEB & Cat\# E2611S & \\
\hline $\begin{array}{l}\text { commercial } \\
\text { assay or kit }\end{array}$ & $\begin{array}{l}\text { Gateway BP } \\
\text { Clonase II enzyme } \\
\text { mix }\end{array}$ & ThermoFisher & Cat\# 11789020 & \\
\hline $\begin{array}{l}\text { commercial } \\
\text { assay or kit }\end{array}$ & $\begin{array}{l}\text { Dip-and-Read } \\
\text { Streptavidin (SA) } \\
\text { biosensors }\end{array}$ & $\begin{array}{l}\text { Molecular } \\
\text { Devices }\end{array}$ & Cat\# 18-5019 & \\
\hline $\begin{array}{l}\text { commercial } \\
\text { assay or kit }\end{array}$ & $\begin{array}{l}\text { HisTrap High } \\
\text { Performance } \\
\text { column }\end{array}$ & GE Healthcare & Cat\# GE17524801 & \\
\hline $\begin{array}{l}\text { commercial } \\
\text { assay or kit }\end{array}$ & $\begin{array}{l}\text { HiTrap Heparin } \\
\text { High Performance } \\
\text { column }\end{array}$ & GE Healthcare & Cat\# GE17040601 & \\
\hline $\begin{array}{l}\text { commercial } \\
\text { assay or kit }\end{array}$ & $\begin{array}{l}\text { HiLoad } 16 / 600 \\
\text { Superdex } 75 p g \\
\text { column }\end{array}$ & GE Healthcare & Cat\# GE28989333 & \\
\hline commercial & Dynabeads MyOne & ThermoFisher & Cat\# 65001 & \\
\hline
\end{tabular}




\begin{tabular}{|c|c|c|c|c|}
\hline assay or kit & Streptavidin C1 & & & \\
\hline $\begin{array}{l}\text { commercial } \\
\text { assay or kit }\end{array}$ & $\begin{array}{l}\text { Amersham Protran } \\
\text { supported Western } \\
\text { blotting } \\
\text { membranes, } \\
\text { nitrocellulose }\end{array}$ & GE Healthcare & Cat\# GE10600016 & $\begin{array}{l}\text { pore size } \\
0.45 \mu \mathrm{m}, \\
\text { for } \\
\text { DRaCALA } \\
\text { assay }\end{array}$ \\
\hline $\begin{array}{l}\text { Recombinant } \\
\text { protein }\end{array}$ & BamHI-HF & NEB & Cat\# R3136S & $\begin{array}{l}20,000 \\
\text { units } / \mathrm{mL}\end{array}$ \\
\hline $\begin{array}{l}\text { Recombinant } \\
\text { protein }\end{array}$ & BamHI & NEB & Cat\# R0136S & $\begin{array}{l}20,000 \\
\text { units } / \mathrm{mL}\end{array}$ \\
\hline $\begin{array}{l}\text { Recombinant } \\
\text { protein }\end{array}$ & EcoRI-HF & NEB & Cat\# R3101S & $\begin{array}{l}20,000 \\
\text { units } / \mathrm{mL}\end{array}$ \\
\hline $\begin{array}{l}\text { Recombinant } \\
\text { protein }\end{array}$ & HindIII-HF & NEB & Cat\# R3104S & $\begin{array}{l}20,000 \\
\text { units } / \mathrm{mL}\end{array}$ \\
\hline $\begin{array}{l}\text { Recombinant } \\
\text { protein }\end{array}$ & Exonuclease VII & NEB & Cat\# M0379s & $\begin{array}{l}10,000 \\
\text { units } / \mathrm{mL}\end{array}$ \\
\hline $\begin{array}{l}\text { Recombinant } \\
\text { protein }\end{array}$ & Exonuclease T7 & NEB & Cat\# M0263S & $\begin{array}{l}10,000 \\
\text { units } / \mathrm{mL}\end{array}$ \\
\hline $\begin{array}{l}\text { chemical } \\
\text { compound, } \\
\text { drug }\end{array}$ & $\begin{array}{l}\text { Benzonase } \\
\text { nuclease }\end{array}$ & Sigma-Aldrich & Cat\# E1014 & \\
\hline $\begin{array}{l}\text { chemical } \\
\text { compound, } \\
\text { drug }\end{array}$ & NTP & ThermoFisher & Cat\# R0481 & $\begin{array}{l}100 \mathrm{mM} \\
\text { solution }\end{array}$ \\
\hline $\begin{array}{l}\text { chemical } \\
\text { compound, } \\
\text { drug }\end{array}$ & CTPyS & $\begin{array}{l}\text { Jena } \\
\text { Bioscience }\end{array}$ & Custom synthesis & $\begin{array}{l}\text { A gift from } \\
\text { S. Gruber } \\
\text { and custom } \\
\text { synthesis } \\
\text { (purity } \geq \\
96 \% \text { ) }\end{array}$ \\
\hline $\begin{array}{l}\text { chemical } \\
\text { compound, } \\
\text { drug }\end{array}$ & CMP-PCP & $\begin{array}{l}\text { Jena } \\
\text { Bioscience }\end{array}$ & Cat\# NU-254 & \\
\hline $\begin{array}{l}\text { chemical } \\
\text { compound, } \\
\text { drug }\end{array}$ & $P^{32}-\alpha-C T P$ & Perkin Elmer & $\begin{array}{l}\text { Cat\# } \\
\text { BLU008H250UC }\end{array}$ & $\begin{array}{l}3000 \\
\mathrm{Ci} / \mathrm{mmol}, 10 \\
\mathrm{mCi} / \mathrm{ml}, 250 \\
\mu \mathrm{Ci}\end{array}$ \\
\hline $\begin{array}{l}\text { chemical } \\
\text { compound, } \\
\text { drug }\end{array}$ & $\begin{array}{l}\text { Anhydrotetracycline } \\
\text { hydrochloride } \\
\text { (ahTc) }\end{array}$ & Abcam & Cat\# ab145350 & $\begin{array}{l}\text { Dissolved in } \\
\text { ethanol }\end{array}$ \\
\hline
\end{tabular}




\begin{tabular}{|l|l|l|l|l|}
\hline $\begin{array}{l}\text { chemical } \\
\text { compound, } \\
\text { drug }\end{array}$ & $\begin{array}{l}\text { Bismaleimidoethan } \\
\text { e (BMOE) }\end{array}$ & ThermoFisher & Cat\# 22323 & $\begin{array}{l}\text { Dissolved in } \\
\text { DMSO }\end{array}$ \\
\hline $\begin{array}{l}\text { software, } \\
\text { algorithm }\end{array}$ & BLItz Pro & $\begin{array}{l}\text { Molecular } \\
\text { Devices }\end{array}$ & $\begin{array}{l}\text { https://www.molecu } \\
\text { lardevices.com/ }\end{array}$ & Version 1.2 \\
\hline $\begin{array}{l}\text { software, } \\
\text { algorithm }\end{array}$ & R & $\begin{array}{l}\text { R Foundation } \\
\text { for Statistical } \\
\text { Computing }\end{array}$ & $\begin{array}{l}\text { RRID: } \\
\text { SCR_001905 }\end{array}$ & $\begin{array}{l}\text { Version } \\
3.2 .4\end{array}$ \\
\hline $\begin{array}{l}\text { software, } \\
\text { algorithm }\end{array}$ & Image Studio Lite & $\begin{array}{l}\text { LI-COR } \\
\text { Biosciences }\end{array}$ & $\begin{array}{l}\text { https://www.licor.co } \\
\text { litio/image-studio- } \\
\text { lite/ }\end{array}$ & Version 5.2 \\
\hline $\begin{array}{l}\text { software, } \\
\text { algorithm }\end{array}$ & Excel 2016 & Microsoft & $\begin{array}{l}\text { https://products.offi } \\
\text { ce.com }\end{array}$ & \\
\hline
\end{tabular}

\section{Protein overexpression and purification}

Full-length Caulobacter ParB (WT) and ParB (R104A) were purified as described previously ${ }^{12}$. Briefly, pET21b::ParB-His 6 (WT or R104A) was introduced into E. coli Rosetta (DE3) competent cells (Merck). A $10 \mathrm{~mL}$ overnight culture was used to inoculate $4 \mathrm{~L}$ of LB medium + carbenicillin + chloramphenicol. Cells were grown at $37^{\circ} \mathrm{C}$ with shaking at $250 \mathrm{rpm}$ to an $\mathrm{OD}_{600}$ of 0.4 . The culture was then left to cool to $4^{\circ} \mathrm{C}$ before isopropyl- $\beta$-D-thiogalactopyranoside (IPTG) was added to a final concentration of $1 \mathrm{mM}$. The culture was shaken for 3 hours at $30^{\circ} \mathrm{C}$ before cells were harvested by centrifugation.

Pelleted cells were resuspended in a buffer containing $100 \mathrm{mM}$ Tris- $\mathrm{HCl} \mathrm{pH} 8.0,300 \mathrm{mM} \mathrm{NaCl}, 10$ $\mathrm{mM}$ Imidazole, $5 \%(\mathrm{v} / \mathrm{v})$ glycerol, $1 \mu \mathrm{L}$ of Benzonase nuclease (Sigma Aldrich), $1 \mathrm{mg}$ of lysozyme (Sigma Aldrich), and an EDTA-free protease inhibitor tablet (Roche). The pelleted cells were then lyzed by sonication. The cell debris was removed via centrifugation at $28,000 \mathrm{~g}$ for $30 \mathrm{~min}$, and the supernatant was filtered through a $0.45 \mu \mathrm{m}$ sterile filter (Sartorius Stedim). The protein was then loaded into a 1-mL HisTrap column (GE Healthcare) that had been equilibrated with buffer A [100 $\mathrm{mM}$ Tris- $\mathrm{HCl} \mathrm{pH} 8.0,300 \mathrm{mM} \mathrm{NaCl}, 10 \mathrm{mM}$ Imidazole, and $5 \%$ glycerol]. Protein was eluted from the column using an increasing $(10 \mathrm{mM}$ to $500 \mathrm{mM})$ imidazole gradient in the same buffer. ParBcontaining fractions were pooled and diluted to a conductivity of $16 \mathrm{mS} / \mathrm{cm}$ before being loaded onto a 1-mL Heparin HP column (GE Healthcare) that had been equilibrated with $100 \mathrm{mM} \mathrm{Tris-HCl}$ $\mathrm{pH}$ 8.0, $25 \mathrm{mM} \mathrm{NaCl}$, and 5\% glycerol. Protein was eluted from the Heparin column using an increasing (25 mM to $1 \mathrm{M} \mathrm{NaCl}$ ) salt gradient in the same buffer. ParB that was used for EnzChek Phosphate assay and DRaCALA was further polished via a gel-filtration column. To do so, purified ParB was concentrated by centrifugation in an Amicon Ultra-15 3-kDa cut-off spin filters (Merck) before being loaded into a Superdex 75 gel filtration column (GE Healthcare). The gel filtration column was pre-equilibrated with $100 \mathrm{mM}$ Tris- $\mathrm{HCl} \mathrm{pH}$ 8.0, $250 \mathrm{mM} \mathrm{NaCl}$, and $1 \mathrm{mM} \mathrm{MgCl}_{2}$.

C-terminally His-tagged TetR (class B, from Tn10) were expressed from E. coli Rosetta DE3) harboring a pET21b::TetR-His 6 plasmid (Supplementary file 1). TetR-His 6 were purified via a onestep Ni-affinity column using the exact buffers as employed for the purification of Caulobacter ParB-His 6 .

C-terminally His-tagged ParB (C297S) and ParB (Q35C C297S) were expressed from E. coli Rosetta (DE3) harboring a pET21b::ParB-His 6 (C297S) or (Q35C C297S) plasmid (Supplementary file 1). ParB-His 6 (C297S) and (Q35C C297S) were purified via a one-step Ni-affinity column using the exact buffers as employed for the purification of Caulobacter ParB-His 6 . ParB (Q35C C297S) 
stock solution was supplemented with TCEP ( $1 \mathrm{mM}$ final concentration) before being flash-frozen in liquid nitrogen.

N-terminally His-tagged MBP-tagged ParB (orthologous proteins from various bacterial species) were expressed from E. coli Rosetta (DE3) harboring pET-His-MBP-TEV-DEST::ParB plasmids (Table S1). His 6 -MBP-ParB proteins were purified via a one-step Ni-affinity column as described previously ${ }^{56}$.

Different batches of proteins were purified by A.S.B.J and N.T.T, and are consistent in all assays used in this work. Both biological (new sample preparations from a fresh stock aliquot) and technical (same sample preparation) replicates were performed for assays described in this study.

\section{Construction of pET21b::ParB-His 6 (C297S and Q35C C297S)}

DNA containing the codon-optimized coding sequence of ParB (C297S or Q35C C297S) was chemically synthesized (gBlocks dsDNA fragments, IDT). These gBlocks fragments and a NdelHindlll-digested pET21b backbone were assembled using a 2x Gibson master mix (NEB). Two and a half $\mu \mathrm{L}$ of each fragment at equimolar concentration was added to $5 \mu \mathrm{L} 2 x$ Gibson master mix (NEB), and the mixture was incubated at $50^{\circ} \mathrm{C}$ for $60 \mathrm{~min}$. Five $\mu \mathrm{L}$ was used to transform chemically competent $E$. coli DH5a cells. Gibson assembly was possible due to a 23-bp sequence shared between the Ndel-HindlII-cut pET21b backbone and the gBlocks fragments. These 23-bp regions were incorporated during the synthesis of gBlocks fragments. The resulting plasmids were sequence verified by Sanger sequencing (Eurofins, Germany).

\section{Construction of pET21b::TetR-His 6}

DNA containing the coding sequence of TetR (class $B$, from Tn10) was chemically synthesized (gBlocks dsDNA fragments, IDT). This gBlocks fragment and a Ndel-Hindlll-digested pET21b backbone were assembled together using a 2x Gibson master mix (NEB). Gibson assembly was possible due to a 23-bp sequence shared between the Ndel-Hindll-cut pET21b backbone and the gBlocks fragment. These 23-bp regions were incorporated during the synthesis of gBlocks fragments. The resulting plasmids were sequence verified by Sanger sequencing (Eurofins, Germany).

\section{Construction of pENTR::ParB orthologs}

The coding sequences of ParB orthologs were chemically synthesized (gBlocks dsDNA fragments, IDT) and cloned into pENTR-D-TOPO backbone (Invitrogen) by Gibson assembly (NEB). The resulting plasmids were sequence verified by Sanger sequencing (Eurofins, Germany).

\section{Construction of pET-His-MBP-TEV-DEST::ParB orthologs}

The parB genes were recombined into a Gateway-compatible destination vector pET-His-MBPTEV-DEST ${ }^{56}$ via an LR recombination reaction (ThermoFisher). For LR recombination reactions: 1 $\mu \mathrm{L}$ of purified pENTR::parB $(\sim 100 \mathrm{ng} / \mu \mathrm{L})$ was incubated with $1 \mu \mathrm{L}$ of the destination vector $\mathrm{pET}$ His-MBP-TEV-DEST ( $100 \mathrm{ng} / \mu \mathrm{L}), 1 \mu \mathrm{L}$ of LR Clonase II enzyme mix, and $2 \mu \mathrm{L}$ of water in a total volume of $5 \mu \mathrm{L}$.

\section{Construction of DNA substrates for BLI assays}

All DNA constructs (Supplementary file 1) were designed in VectorNTI (Thermo Fisher) and were chemically synthesized (gBlocks dsDNA fragments, IDT). All linear DNA constructs were designed with M13F and M13R homologous regions at each end. To generate a dual biotin-labeled DNA substrate, PCR reactions were performed using a 2x GoTaq PCR master mix (Promega), biotinlabeled M13F and biotin-labeled M13R primers, and gBlocks fragments as template. PCR products were resolved by electrophoresis and gel purified.

Measurement of protein-DNA interaction by bio-layer interferometry (BLI) 
bioRxiv preprint doi: https://doi.org/10.1101/2019.12.11.865972; this version posted February 20, 2020. The copyright holder for this preprint (which was not certified by peer review) is the author/funder. All rights reserved. No reuse allowed without permission.

Bio-layer interferometry experiments were conducted using a BLItz system equipped with Dip-andRead Streptavidin (SA) Biosensors (Molecular Devices). BLItz monitors wavelength shifts (nm) resulting from changes in the optical thickness of the sensor surface during association or dissociation of the analyte. All BLI experiments were performed at $22^{\circ} \mathrm{C}$. The streptavidin biosensor was hydrated in a low-salt binding buffer [100 mM Tris-HCl pH 8.0, $100 \mathrm{mM} \mathrm{NaCl}, 1 \mathrm{mM}$ $\mathrm{MgCl}_{2}$, and $0.005 \%$ Tween 20] for at least $10 \mathrm{~min}$ before each experiment. Biotinylated doublestranded DNA (dsDNA) was immobilized onto the surface of the SA biosensor through a cycle of Baseline (30 sec), Association (120 sec), and Dissociation $(120 \mathrm{sec})$. Briefly, the tip of the biosensor was dipped into a binding buffer for $30 \mathrm{sec}$ to establish the baseline, then to $1 \mu \mathrm{M}$ biotinylated dsDNA for $120 \mathrm{sec}$, and finally to a low salt binding buffer for $120 \mathrm{sec}$ to allow for dissociation.

After the immobilization of DNA on the sensor, association reactions were monitored at $1 \mu \mathrm{M}$ dimer concentration of ParB (with or without $1 \mu \mathrm{M}$ TetR or NTPs at various concentrations) for 120 sec or $60 \mathrm{~min}$ (Figure 6A). At the end of each binding step, the sensor was transferred into a protein-free binding buffer to follow the dissociation kinetics for $120 \mathrm{sec}$. The sensor can be recycled by dipping in a high-salt buffer [100 mM Tris- $\mathrm{HCl}$ pH 8.0, $1000 \mathrm{mM} \mathrm{NaCl}, 1 \mathrm{mM} \mathrm{MgCl}$, and $0.005 \%$ Tween 20] for 5 min to remove bound ParB.

For experiments where a closed DNA was cleaved to generate a free DNA end, DNA-coated tips were dipped into $300 \mu \mathrm{L}$ of cutting solution [266 $\mu \mathrm{L}$ of water, $30 \mu \mathrm{L}$ of $10 x$ CutSmart buffer (NEB), and $4 \mu \mathrm{L}$ of EcoRI-HF or BamHI-HF restriction enzyme $(20,000$ units $/ \mathrm{mL})]$ for 30 min at $37^{\circ} \mathrm{C}$.

For experiments described in Figure 1-figure supplement 2, $\mathrm{MgCl}_{2}$ was omitted from all binding and protein storage buffers.

For experiments described in Figure 3-figure supplement 2, bio-layer interferometry assays were performed using 1x NEB 3.1 buffer [100 mM NaCl, $50 \mathrm{mM}$ Tris- $\mathrm{HCl} \mathrm{pH}$ 7.9, $10 \mathrm{mM} \mathrm{MgCl}$, 100 $\mu \mathrm{g} / \mathrm{ml} \mathrm{BSA}$ ] instead of the low-salt binding buffer [100 mM NaCl, $10 \mathrm{mM}$ Tris-HCl pH 8.0, $1 \mathrm{mM}$ $\mathrm{MgCl}_{2}, 0.005 \%$ Tween20]. After incubating $1 \mu \mathrm{M}$ ParB and $1 \mathrm{mM}$ CTP with a $169 \mathrm{bp}$ parS-coated probe for $120 \mathrm{sec}, 4 \mu \mathrm{L}$ of $\mathrm{BamHI}(20,000$ units $/ \mathrm{mL})$ or heat-inactivated BamHI was added to a 300 $\mu \mathrm{L}$ reaction to start digesting bound DNA. The reaction was monitored for an additional $30 \mathrm{~min}$. $\mathrm{BamHI}$ was inactivated by heat at $65^{\circ} \mathrm{C}$ for $30 \mathrm{~min}$.

For experiments described in Figure 4-figure supplement 1, $3 \mu \mathrm{M}$ of anhydrotetracycline (ahTc) was used to remove bound TetR from DNA. After incubating $1 \mu \mathrm{M}$ ParB and $1 \mathrm{mM}$ CTP $\pm 1 \mu \mathrm{M}$ TetR with a 170-bp parS-coated probe for $120 \mathrm{sec}$, ahTc (dissolved in ethanol) or ethanol alone was added to a $300 \mu \mathrm{L}$ reaction to the final concentration of $3 \mu \mathrm{M}$ or $0.01 \%$, respectively. The reaction was monitored for an additional $120 \mathrm{sec}$.

All sensorgrams recorded during BLI experiments were analyzed using the BLItz analysis software (BLItz Pro version 1.2, Molecular Devices) and replotted in $\mathrm{R}$ for presentation. Each experiment was triplicated, the standard deviation of triplicated sensorgrams is less than ten percent, and a representative sensorgram was presented in each figure.

To verify that dual biotin-labeled DNA fragments formed a closed substrate on the surface of the BLI probe, we performed a double digestion with Exonuclease T7 and Exonuclease VII (NEB) (Figure 2-figure supplement 1). DNA-coated tips were dipped into $300 \mu \mathrm{L}$ of cutting solution [266 $\mu \mathrm{L}$ of water, $30 \mu \mathrm{L}$ of $10 \mathrm{x}$ RE buffer 4 (NEB), $2 \mu \mathrm{L}$ of exonuclease T7 $(10,000$ units $/ \mathrm{mL})$ and $2 \mu \mathrm{L}$ of exonuclease VII $(10,000$ units $/ \mathrm{mL})]$ for $30 \mathrm{~min}$ at $25^{\circ} \mathrm{C}$. Tips were then cut off from the plastic adaptor (Figure 2-figure supplement 1) and immerged into a 1x GoTaq PCR master mix [25 $\mu \mathrm{L}$ water, $25 \mu \mathrm{L} 2 \mathrm{x}$ GoTaq master mix, $0.5 \mu \mathrm{L}$ of $100 \mu \mathrm{M}$ M13F oligo, and $0.5 \mu \mathrm{L}$ of $100 \mu \mathrm{M}$ M13R oligo]. Ten cycles of PCR were performed, and the PCR products were resolved on $2 \%$ agarose gels (Figure 2-figure supplement 1). 
bioRxiv preprint doi: https://doi.org/10.1101/2019.12.11.865972; this version posted February 20, 2020. The copyright holder for this

NTP (stock concentration: $100 \mathrm{mM}$ ) used in BLI assays was purchased from ThermoFisher. CTPYS (stock concentration: $90 \mathrm{mM}$ ) was a generous gift from Stephan Gruber and Young-Min Soh. CTPYS was also custom-synthesized and re-purified to $96 \%$ purity (Jena Bioscience). Another non-hydrolyzable analog CMP-PCP (Jena Bioscience) was unsuitable for our assays as Caulobacter ParB does not bind CMP-PCP (Figure 6-figure supplement 1).

\section{Construction of DNA substrates for pull-down assays}

A 260-bp DNA fragment containing Caulobacter parS sites (genomic position: 4034789-4035048) 12 or scrambled parS sites were chemically synthesized (gBlocks fragments, IDT). These DNA fragments were subsequently 5' phosphorylated using T4 PNK enzyme (NEB), then cloned into a Smal-cut pUC19 using T4 DNA ligase (NEB). The two resulting plasmids are pUC19::260bp-parS and pUC19::260bp-scrambled parS (Supplementary file 1). These plasmids were sequence verified by Sanger sequencing (Eurofins, Germany). To generate dual biotin-labeled DNA substrates, we performed PCR using a pair of biotinylated primers: around_pUC19_F and around_pUC19_R, and either pUC19::260bp-parS or pUC19::260bp-scrambled pars as a template. Phusion DNA polymerase (NEB) was employed for this round-the-horn PCR reaction. The resulting $\sim 2.8-\mathrm{kb}$ linear DNA fragments were gel-purified and eluted in $50 \mu \mathrm{L}$ of autoclaved distilled water.

\section{Pull-down assays}

Paramagnetic MyOne Streptavidin C1 Dyna beads (ThermoFisher) were used for pull-down assays. Thirty $\mu \mathrm{L}$ of beads were washed twice in $500 \mu \mathrm{L}$ of high-salt wash buffer $[100 \mathrm{mM}$ Tris- $\mathrm{HCl}$ $\mathrm{pH}$ 8.0, $1 \mathrm{M} \mathrm{NaCl}, 1 \mathrm{mM} \mathrm{MgCl}$, and $0.005 \%$ Tween 20] and once in $100 \mu \mathrm{L}$ binding buffer [100 $\mathrm{mM}$ Tris- $\mathrm{HCl} \mathrm{pH} \mathrm{8.0,100} \mathrm{mM} \mathrm{NaCl}, 1 \mathrm{mM} \mathrm{MgCl}_{2}$, and $0.005 \%$ Tween 20] by repeating a cycle of resuspension and pull-down by magnetic attraction. Five $\mu \mathrm{L}$ of $\sim 50 \mathrm{nM}$ dual biotin-labeled DNA substrate was incubated with $30 \mu \mathrm{L}$ of beads in $100 \mu \mathrm{L}$ binding buffer for $30 \mathrm{~min}$ at room temperature. The reaction was occasionally mixed by pipetting up and down several times. Afterward, DNA-coated beads were washed once in $500 \mu \mathrm{L}$ high-salt buffer [100 mM Tris- $\mathrm{HCl} \mathrm{pH}$ 8.0, $1000 \mathrm{mM} \mathrm{NaCl}, 1 \mathrm{mM} \mathrm{MgCl} 2$, and $0.005 \%$ Tween 20] and once in $500 \mu \mathrm{L}$ of binding buffer. Finally, DNA-coated beads were resuspended in $300 \mu \mathrm{L}$ of binding buffer. Ninety-six $\mu \mathrm{L}$ of the resuspended beads were used for each pull-down assay. Four $\mu \mathrm{L}$ of Caulobacter ParB-His 6 (WT) or (R104A) (stock concentration: $25 \mu \mathrm{M}$ ) were added to $96 \mu \mathrm{L}$ of suspended beads. NTPs were either omitted or added to the suspended beads to the final concentration of $1 \mathrm{mM}$. The mixture was pipetted up and down several times and was left to incubate at room temperature for 5 min. Beads were then pulled down magnetically and unwanted supernatant discarded. DNA-coated beads (now with bound protein) were then washed once with $500 \mu \mathrm{L}$ of binding buffer and once with $100 \mu \mathrm{L}$ of the same buffer. The unwanted supernatant was discarded, and the left-over beads were resuspended in $30 \mu \mathrm{L}$ of $1 \times$ SDS-PAGE sample buffer. Each experiment was triplicated, and a representative immunoblot was presented.

\section{Immunoblot analysis}

For immunoblot analysis, magnetic beads were resuspended directly in 1x SDS sample buffer, then heated to $42^{\circ} \mathrm{C}$ for $15 \mathrm{~min}$ before loading to $12 \%$ Novex Tris-Glycine SDS-PAGE gels (ThermoFisher). The eluted protein was resolved by electrophoresis at $150 \mathrm{~V}$ for $60 \mathrm{~min}$. Resolved proteins were transferred to polyvinylidene fluoride membranes using the Trans-Blot Turbo Transfer System (BioRad) and probed with 1:5,000 dilution of $\alpha$-His 6 HRP-conjugated antibody (Abcam). Blots were imaged and analyzed using an Amersham Imager 600 (GE Healthcare) and Image Studio Lite version 5.2 (LI-COR Biosciences). The band intensities were quantified for lanes 5 and 6 (Figure $2 \mathrm{C}$ ), and the range of fold difference between replicates was reported.

\section{Differential radial capillary action of ligand assay (DRaCALA) or membrane-spotting assay}


Purified Caulobacter ParB-His ${ }_{6}$ or TetR-His ${ }_{6}$ (final concentration: $25 \mu \mathrm{M}$ ) were incubated with $5 \mathrm{nM}$ radiolabeled $\mathrm{P}^{32}$ - $\alpha$-CTP (Perkin Elmer), $30 \mu \mathrm{M}$ of unlabeled cold CTP (Thermo Fisher), $1.5 \mu \mathrm{M}$ of 22-bp parS or NBS DNA duplex in the reaction buffer [100 mM Tris pH 8.0, $100 \mathrm{mM} \mathrm{NaCl}$, and 10 $\mathrm{mM} \mathrm{MgCl}$ ] for 5 minutes at room temperature. For the NTP competition assay, the mixture was further supplemented with $500 \mu \mathrm{M}$ of either unlabeled cold CTP, ATP, GTP, or UTP. Four $\mu \mathrm{L}$ of samples were spotted slowly onto a dry nitrocellulose membrane and air-dried. The nitrocellulose membrane was wrapped in cling film before being exposed to a phosphor screen (GE Healthcare) for two minutes. Each DRaCALA assay was triplicated, and a representative autoradiograph was shown.

\section{DNA preparation for EnzCheck Phosphate assay and DRaCALA}

A 22-bp palindromic single-stranded DNA fragment (parS: GGATGTTTCACGTGAAACA TCC or NBS: GGATATTTCCCGGGAAATATCC) [100 $\mu \mathrm{M}$ in $1 \mathrm{mM}$ Tris-HCl pH 8.0, $5 \mathrm{mM} \mathrm{NaCl}$ buffer] was heated at $98^{\circ} \mathrm{C}$ for 5 min before being left to cool down to room temperature overnight to form 50 $\mu \mathrm{M}$ double-stranded parS or NBS DNA. The sequences of parS and NBS are underlined.

\section{Measurement of NTPase activity by EnzCheck Phosphate assay}

NTP hydrolysis was monitored using an EnzCheck Phosphate Assay Kit (Thermo Fisher). Samples $(100 \mu \mathrm{L})$ containing a reaction buffer supplemented with $1 \mathrm{mM}$ of NTP and $1 \mu \mathrm{M}$ ParB (WT or $\mathrm{R} 104 \mathrm{~A}$ ) were assayed in a Biotek EON plate reader at $25^{\circ} \mathrm{C}$ for 15 hours with readings every minute. The reaction buffer $(1 \mathrm{~mL})$ typically contained: $740 \mu \mathrm{L}$ Ultrapure water, $50 \mu \mathrm{L} 20 \mathrm{x}$ customized reaction buffer [100 mM Tris pH 8.0, $2 \mathrm{M} \mathrm{NaCl}$, and $20 \mathrm{mM} \mathrm{MgCl}$ ], $200 \mu \mathrm{L}$ MESG substrate solution, and $10 \mu \mathrm{L}$ purine nucleoside phosphorylase (1 unit). Reactions with buffer only, buffer + protein only or buffer + NTP only were also included as controls. The plates were shaken at $280 \mathrm{rpm}$ continuously for 15 hours at $25^{\circ} \mathrm{C}$. The inorganic phosphate standard curve was also constructed according to the manual. Each assay was triplicated. The results were analyzed using $R$ and the NTPase rates were calculated using a linear regression fitting in $R$.

\section{In vitro crosslinking using a sulfhydryl-to-sulfhydryl crosslinker bismaleimidoethane (BMOE)}

A $50 \mu \mathrm{L}$ mixture of $10 \mu \mathrm{M}$ ParB (C297S) or (C297S Q35C) $\pm 1 \mathrm{mM}$ NTP $\pm 0.5 \mu \mathrm{M}$ parS dsDNA (22 bp) was assembled in a reaction buffer [10 mM Tris- $\mathrm{HCl} \mathrm{pH} 7.4,100 \mathrm{mM} \mathrm{NaCl}$, and $1 \mathrm{mM} \mathrm{MgCl}$ ] and incubated for 15 min (Figure 6-figure supplement 2B) or for 1, 5, 10, 15, and 30 min (Figure $6 \mathrm{~B})$ at room temperature. BMOE (1 mM final concentration from a $20 \mathrm{mM}$ stock solution) was then added, and the reaction was quickly mixed by three pulses of vortexing. SDS-PAGE sample buffer containing $23 \mathrm{mM} \beta$-mercaptoethanol was then added immediately to quench the crosslinking reaction. Samples were heated to $50^{\circ} \mathrm{C}$ for $15 \mathrm{~min}$ before being loaded on $12 \%$ TruPAGE TrisGlycine Precast gels (Sigma Aldrich). Each assay was triplicated. Gels were stained with InstantBlue solution (Expedeon) and band intensity was quantified using Image Studio Lite version 5.2 (LI-COR Biosciences). The crosslinked fractions were averaged, and their standard deviations calculated in Excel.

\section{REFERENCES}

1. Donczew, M. et al. ParA and ParB coordinate chromosome segregation with cell elongation and division during Streptomyces sporulation. Open Biology 6, 150263 (2016).

2. Fogel, M. A. \& Waldor, M. K. A dynamic, mitotic-like mechanism for bacterial chromosome segregation. Genes Dev. 20, 3269-3282 (2006).

3. Gruber, S. \& Errington, J. Recruitment of condensin to replication origin regions by ParB/SpoOJ promotes chromosome segregation in B. subtilis. Cell 137, 685-96 (2009).

4. Harms, A., Treuner-Lange, A., Schumacher, D. \& Sogaard-Andersen, L. Tracking of chromosome and replisome dynamics in Myxococcus xanthus reveals a novel chromosome arrangement. PLoS Genet 9, e1003802 (2013). 
5. Ireton, K., Gunther, N. W. \& Grossman, A. D. spo0J is required for normal chromosome segregation as well as the initiation of sporulation in Bacillus subtilis. J. Bacteriol. 176, 53205329 (1994).

6. Jakimowicz, D., Chater, K. \& Zakrzewska-Czerwi'nska, J. The ParB protein of Streptomyces coelicolor $A 3(2)$ recognizes a cluster of parS sequences within the origin-proximal region of the linear chromosome. Molecular Microbiology 45, 1365-1377 (2002).

7. Kawalek, A., Bartosik, A. A., Glabski, K. \& Jagura-Burdzy, G. Pseudomonas aeruginosa partitioning protein ParB acts as a nucleoid-associated protein binding to multiple copies of a parS-related motif. Nucleic Acids Res. 46, 4592-4606 (2018).

8. Lin, D. C.-H. \& Grossman, A. D. Identification and Characterization of a Bacterial Chromosome Partitioning Site. Cell 92, 675-685 (1998).

9. Livny, J., Yamaichi, Y. \& Waldor, M. K. Distribution of Centromere-Like parS Sites in Bacteria: Insights from Comparative Genomics. J. Bacteriol. 189, 8693-8703 (2007).

10. Mohl, D. A., Easter, J. \& Gober, J. W. The chromosome partitioning protein, ParB, is required for cytokinesis in Caulobacter crescentus. Mol. Microbiol. 42, 741-755 (2001).

11. Sullivan, N. L., Marquis, K. A. \& Rudner, D. Z. Recruitment of SMC by ParB-parS organizes the origin region and promotes efficient chromosome segregation. Cell 137, 697-707 (2009).

12. Tran, N. T. et al. Permissive zones for the centromere-binding protein ParB on the Caulobacter crescentus chromosome. Nucleic Acids Res 46, 1196-1209 (2018).

13. Wang, X., Brandão, H. B., Le, T. B. K., Laub, M. T. \& Rudner, D. Z. Bacillus subtilis SMC complexes juxtapose chromosome arms as they travel from origin to terminus. Science $\mathbf{3 5 5}$, 524-527 (2017).

14. Toro, E., Hong, S.-H., McAdams, H. H. \& Shapiro, L. Caulobacter requires a dedicated mechanism to initiate chromosome segregation. PNAS 105, 15435-15440 (2008).

15. Lagage, V., Boccard, F. \& Vallet-Gely, I. Regional Control of Chromosome Segregation in Pseudomonas aeruginosa. PLOS Genetics 12, e1006428 (2016).

16. Breier, A. M. \& Grossman, A. D. Whole-genome analysis of the chromosome partitioning and sporulation protein Spo0J (ParB) reveals spreading and origin-distal sites on the Bacillus subtilis chromosome. Molecular Microbiology 64, 703-718 (2007).

17. Murray, H., Ferreira, H. \& Errington, J. The bacterial chromosome segregation protein Spo0J spreads along DNA from parS nucleation sites. Molecular Microbiology 61, 1352-1361 (2006).

18. Taylor, J. A. et al. Specific and non-specific interactions of ParB with DNA: implications for chromosome segregation. Nucleic Acids Res 43, 719-731 (2015).

19. Graham, T. G. W. et al. ParB spreading requires DNA bridging. Genes Dev. 28, 1228-1238 (2014).

20. Sanchez, A. et al. Stochastic Self-Assembly of ParB Proteins Builds the Bacterial DNA Segregation Apparatus. Cell Syst. 1, 163-173 (2015).

21. Debaugny, R. E. et al. A conserved mechanism drives partition complex assembly on bacterial chromosomes and plasmids. Mol. Syst. Biol. 14, e8516 (2018).

22. Broedersz, C. P. et al. Condensation and localization of the partitioning protein ParB on the bacterial chromosome. PNAS 111, 8809-8814 (2014).

23. Funnell, B. E. ParB Partition Proteins: Complex Formation and Spreading at Bacterial and Plasmid Centromeres. Front Mol Biosci 3, 44 (2016).

24. Tran, N. T., Laub, M. T. \& Le, T. B. K. SMC Progressively Aligns Chromosomal Arms in Caulobacter crescentus but Is Antagonized by Convergent Transcription. Cell Rep 20, 20572071 (2017).

25. Minnen, A., Attaiech, L., Thon, M., Gruber, S. \& Veening, J.-W. SMC is recruited to oriC by ParB and promotes chromosome segregation in Streptococcus pneumoniae. Mol. Microbiol. 81, 676-688 (2011).

26. Lim, H. C. et al. Evidence for a DNA-relay mechanism in ParABS-mediated chromosome segregation. Elife 3, e02758 (2014).

27. Vecchiarelli, A. G., Neuman, K. C. \& Mizuuchi, K. A propagating ATPase gradient drives transport of surface-confined cellular cargo. Proc. Natl. Acad. Sci. U.S.A. 111, 4880-4885 (2014). 
28. Vecchiarelli, A. G., Mizuuchi, K. \& Funnell, B. E. Surfing biological surfaces: exploiting the nucleoid for partition and transport in bacteria. Molecular Microbiology 86, 513-523 (2012).

29. Hwang, L. C. et al. ParA-mediated plasmid partition driven by protein pattern self-organization. The EMBO Journal 32, 1238-1249 (2013).

30. Leonard, T. A., Butler, P. J. \& Löwe, J. Bacterial chromosome segregation: structure and DNA binding of the Soj dimer--a conserved biological switch. EMBO J. 24, 270-282 (2005).

31. Jecz, P., Bartosik, A. A., Glabski, K. \& Jagura-Burdzy, G. A single parS sequence from the cluster of four sites closest to oriC is necessary and sufficient for proper chromosome segregation in Pseudomonas aeruginosa. PLoS ONE 10, e0120867 (2015).

32. Attaiech, L., Minnen, A., Kjos, M., Gruber, S. \& Veening, J.-W. The ParB-parS Chromosome Segregation System Modulates Competence Development in Streptococcus pneumoniae. mBio 6, e00662-15 (2015).

33. Yu, W., Herbert, S., Graumann, P. L. \& Götz, F. Contribution of SMC (Structural Maintenance of Chromosomes) and SpolllE to Chromosome Segregation in Staphylococci. J Bacteriol 192, 4067-4073 (2010).

34. Lee, P. S. \& Grossman, A. D. The chromosome partitioning proteins Soj (ParA) and Spo0J (ParB) contribute to accurate chromosome partitioning, separation of replicated sister origins, and regulation of replication initiation in Bacillus subtilis. Mol. Microbiol. 60, 853-869 (2006).

35. Lynch, A. S. \& Wang, J. C. SopB protein-mediated silencing of genes linked to the sopC locus of Escherichia coli F plasmid. PNAS 92, 1896-1900 (1995).

36. Rodionov, O., Lobocka, M. \& Yarmolinsky, M. Silencing of genes flanking the P1 plasmid centromere. Science 283, 546-549 (1999).

37. Chen, B.-W., Lin, M.-H., Chu, C.-H., Hsu, C.-E. \& Sun, Y.-J. Insights into ParB spreading from the complex structure of Spo0J and parS. Proc. Natl. Acad. Sci. U.S.A. 112, 6613-6618 (2015).

38. Surtees, J. A. \& Funnell, B. E. The DNA Binding Domains of P1 ParB and the Architecture of the P1 Plasmid Partition Complex. J. Biol. Chem. 276, 12385-12394 (2001).

39. Ah-Seng, Y., Rech, J., Lane, D. \& Bouet, J.-Y. Defining the role of ATP hydrolysis in mitotic segregation of bacterial plasmids. PLoS Genet. 9, e1003956 (2013).

40. Fisher, G. L. et al. The structural basis for dynamic DNA binding and bridging interactions which condense the bacterial centromere. Elife 6, (2017).

41. Madariaga-Marcos, J., Pastrana, C. L., Fisher, G. L., Dillingham, M. S. \& Moreno-Herrero, F. ParB dynamics and the critical role of the CTD in DNA condensation unveiled by combined force-fluorescence measurements. Elife 8, (2019).

42. Osorio-Valeriano, M. et al. ParB-type DNA Segregation Proteins Are CTP-Dependent Molecular Switches. Cell 179, 1512-1524.e15 (2019).

43. Soh, Y.-M. et al. Self-organization of parS centromeres by the ParB CTP hydrolase. Science (2019) doi:10.1126/science.aay3965.

44. Easter, J. \& Gober, J. W. ParB-Stimulated Nucleotide Exchange Regulates a Switch in Functionally Distinct ParA Activities. Molecular Cell 10, 427-434 (2002).

45. Figge, R. M., Easter, J. \& Gober, J. W. Productive interaction between the chromosome partitioning proteins, ParA and ParB, is required for the progression of the cell cycle in Caulobacter crescentus. Mol. Microbiol. 47, 1225-1237 (2003).

46. Saenger, W., Orth, P., Kisker, C., Hillen, W. \& Hinrichs, W. The Tetracycline Repressor-A Paradigm for a Biological Switch. Angewandte Chemie International Edition 39, 2042-2052 (2000).

47. Onn, I. \& Koshland, D. In vitro assembly of physiological cohesin/DNA complexes. PNAS 108, 12198-12205 (2011).

48. Wu, L. J. \& Errington, J. Coordination of cell division and chromosome segregation by a nucleoid occlusion protein in Bacillus subtilis. Cell 117, 915-925 (2004).

49. Thanbichler, M. \& Shapiro, L. MipZ, a Spatial Regulator Coordinating Chromosome Segregation with Cell Division in Caulobacter. Cell 126, 147-162 (2006). 
50. Kusiak, M., Gapczyńska, A., Płochocka, D., Thomas, C. M. \& Jagura-Burdzy, G. Binding and Spreading of ParB on DNA Determine Its Biological Function in Pseudomonas aeruginosa. $J$. Bacteriol. 193, 3342-3355 (2011).

51. Lin, D. C., Levin, P. A. \& Grossman, A. D. Bipolar localization of a chromosome partition protein in Bacillus subtilis. Proc. Natl. Acad. Sci. U.S.A. 94, 4721-4726 (1997).

52. Glaser, P. et al. Dynamic, mitotic-like behavior of a bacterial protein required for accurate chromosome partitioning. Genes Dev. 11, 1160-1168 (1997).

53. Erdmann, N., Petroff, T. \& Funnell, B. E. Intracellular localization of P1 ParB protein depends on ParA and parS. Proc Natl Acad Sci U S A 96, 14905-14910 (1999).

54. Song, D., Rodrigues, K., Graham, T. G. W. \& Loparo, J. J. A network of cis and trans interactions is required for ParB spreading. Nucleic Acids Res. 45, 7106-7117 (2017).

55. Badrinarayanan, A., Le, T. B. K. \& Laub, M. T. Rapid pairing and resegregation of distant homologous loci enables double-strand break repair in bacteria. J Cell Biol 210, 385-400 (2015).

56. Jalal, A. S. B. et al. Evolving a new protein-DNA interface via sequential introduction of permissive and specificity-switching mutations. bioRxiv 724823 (2019) doi:10.1101/724823. 
SUPPLEMENT TABLE S1. PLASMIDS, DNA, AND PROTEIN SEQUENCES

\begin{tabular}{|c|c|c|}
\hline Plasmids/DNA & Description & Source \\
\hline pET21b::Caulobacter ParB-His 6 & $\begin{array}{l}\text { Overexpression of C-terminally His }{ }_{6} \text {-tagged Caulobacter ParB, carbenicillin } \\
\text { > Caulobacter ParB-His }{ }_{6} \\
\text { MSEGRRGLGRGLSLLGEVDAAPAQ }{ }^{35} \text { APGEQLGGSREAPIEILQRNPDQ } \\
\text { PRRTFREEDLEDLSNSIREKGVLQPILVRPSPDTAGEYQIVAGERR }{ }^{104 W R A} \\
\text { AQRAGLKTVPIMVRELDDLAVLEIGIIENVQRADLNVLEEALSYKVLMEKF } \\
\text { ERTQENIAQTIGKSRSHVANTMRLLALPDEVQSYLVSGELTAGHARAIAA } \\
\text { AADPVALAKQIIEGGLSVRETEALARKAPNLSAGKSKGGRPPRVKTDT } \\
\text { QALESDLSSVLGLDVSIDHRGSTGTLTITYATLEQLDDLC }{ }^{297 N R L T R G I K L A A ~} \\
\text { ALEHHHHHH* (numbering according to }{ }^{1} \text { ) }\end{array}$ & $\begin{array}{l}\text { Gift from C. Jacob- } \\
\text { Wagner }^{2}\end{array}$ \\
\hline pET21b::Caulobacter ParB-His 6 (C297S) & $\begin{array}{l}\text { Overexpression of C-terminally His }{ }_{6} \text {-tagged Caulobacter ParB (C297S), } \\
\text { carbenicillin }^{R}\end{array}$ & This study \\
\hline $\begin{array}{l}\text { pET21b::Caulobacter ParB-His } 6 \text { (Q35C } \\
\text { C297S) }\end{array}$ & $\begin{array}{l}\text { Overexpression of C-terminally His } 6 \text {-tagged Caulobacter ParB (Q35C } \\
\text { C297S), carbenicillin }\end{array}$ & This study \\
\hline pET21b::TetR-His 6 & $\begin{array}{l}\text { Overexpression of C-terminally His }{ }_{6} \text {-tagged TetR (class B, from Tn10), } \\
\text { carbenicillin }^{R} \\
\text { >TetR (class B, from Tn10)-His } 6 \\
\text { MSRLDKSKVINSALELLNEVGIEGLTTRKLAQKLGVEQPTLYWHVKNKRALL } \\
\text { DALAIEMLDRHHTHFCPLEGESWQDFLRNNAKSFRCALLSHRDGAKVHL } \\
\text { GTRPTEKQYETLENQLAFLCQQGFSLENALYALSAVGHFTLGCVLEDQEH } \\
\text { QVAKEERETPTTDSMPPLLRQAIELFDHQGAEPAFLFGLELIICGLEKQLKC } \\
\text { ESGSKLAAALEHHHHHH* }\end{array}$ & This study \\
\hline pUC19::260bp-parS & $\begin{array}{l}\text { pUC19 plasmid with 260-bp insert that contains parS sites, } \\
\text { carbenicillin }{ }^{\mathrm{R}} \\
\text { >260-bp_natural_Caulobacter_parS_fragment_cloned_into_pUC19 } \\
\text { caagacgctcgcctcaatgcgaacgccccgggttcgagcgggggcg } \\
\text { ctggactcgatctatacgccaatcaggcgagcgggtcgatgtgactcatc } \\
\text { ggcgtttcacgtgaaacaccccaccgcagctgtgagcggcctgtggac } \\
\text { aatattggggatgttccacgtgaaacatcacttgccgatacagaaggtcg }\end{array}$ & This study \\
\hline
\end{tabular}




\begin{tabular}{|c|c|c|}
\hline & $\begin{array}{l}\text { aaaagacccgtccaagaacgtcctcaggatcgatacggccggagatg } \\
\text { cgctccagggcccgggc }\end{array}$ & \\
\hline pUC19::260bp-scrambled parS & $\begin{array}{l}\text { pUC19 plasmid with 260-bp insert that contains scrambled parS } \\
\text { sites, carbenicillin }{ }^{R} \\
\text { >260-bp_scrambled_Caulobacter_parS_fragment_cloned_into_pUC19 } \\
\text { caagacgctcgcctcaatgcgaacgccccgggttcgagcgggggcg } \\
\text { ctggactcgatctatacgccaatcaggcgagcgggtcgatgtgactcatc } \\
\text { ggacagctcgagattcatcccccaccgcagctgtgagcggcctgtggac } \\
\text { aatattggggaatcgagtatacgctactcacttgccgatacagaaggtcg } \\
\text { aaaagacccgtccaagaacgtcctcaggatcgatacggccggagatg } \\
\text { cgctccagggcccgggc }\end{array}$ & This study \\
\hline $\begin{array}{l}\text { pET-His-MBP-TEV-DEST::Sinorhizobium } \\
\text { meliloti ParB }\end{array}$ & For the purification of Sinorhizobium meliloti His 6 -MBP-ParB & 3 \\
\hline $\begin{array}{l}\text { pET-His-MBP-TEV-DEST::Rhodobacter } \\
\text { sphaeroides ParB }\end{array}$ & For the purification of Rhodobacter sphaeroides $\mathrm{His}_{6}-\mathrm{MBP}-\mathrm{ParB}$ & This study \\
\hline $\begin{array}{l}\text { pET-His-MBP-TEV-DEST::Thermus } \\
\text { thermophilus ParB }\end{array}$ & For the purification of Thermus thermophilus His $_{6}-\mathrm{MBP}-\mathrm{ParB}$ & 3 \\
\hline $\begin{array}{l}\text { pET-His-MBP-TEV- } \\
\text { DEST::Dechloromonas aromatica ParB }\end{array}$ & For the purification of Dechloromonas aromatica $\mathrm{His}_{6}-\mathrm{MBP}-\mathrm{ParB}$ & This study \\
\hline $\begin{array}{l}\text { pET-His-MBP-TEV-DEST::Psychrobacter } \\
\text { spp. ParB }\end{array}$ & For the purification of Psychrobacter spp. $\mathrm{His}_{6}-\mathrm{MBP}-\mathrm{ParB}$ & This study \\
\hline $\begin{array}{l}\text { pET-His-MBP-TEV- } \\
\text { DEST::Staphylococcus aureus ParB }\end{array}$ & For the purification of Staphylococcus aureus $\mathrm{His}_{6}-\mathrm{MBP}-\mathrm{ParB}$ & 3 \\
\hline $\begin{array}{l}\text { pET-His-MBP-TEV-DEST::Zymomonas } \\
\text { mobilis ParB }\end{array}$ & For the purification of Zymomonas mobilis $\mathrm{His}_{6}-\mathrm{MBP}-\mathrm{ParB}$ & This study \\
\hline $\begin{array}{l}\text { pET-His-MBP-TEV-DEST::Xanthomonas } \\
\text { campestris ParB }\end{array}$ & For the purification of Xanthomonas campestris His 6 -MBP-ParB & 3 \\
\hline 169bp_parS & $\begin{array}{l}\text { cgccagggttttcccagtcacgacgttgtaaaacgacggccagtgaattcgagctcggtac } \\
\text { ccgcaggaggacgtagggtagggggatgtttcacgtgaaacaggggatcctctagagtc } \\
\text { gacctgcaggcatgcaagcttggcgtaatcatggtcatagctgtttcct }\end{array}$ & This study \\
\hline
\end{tabular}




\begin{tabular}{|c|c|c|}
\hline 169bp_scrambled_parS & $\begin{array}{l}\text { cgccagggttttcccagtcacgacgttgtaaaacgacggccagtgaattcgagctcggtacc } \\
\text { cgcaggaggacgtagggtagggggaaattacactgagtttaggggatcctctagagtcga } \\
\text { cctgcaggcatgcaagcttggcgtaatcatggtcatagctgttcct }\end{array}$ & This study \\
\hline 170bp_parS & $\begin{array}{l}\text { cgccagggttttcccagtcacgacgttgtaaaacgacggccagaattcgcaacgtg } \\
\text { tgtttcacgtgaaacagccttgaaactgataacgactctatcattgatagagtgttctct } \\
\text { ccacgggatccccaggcatgcaagcttggcgtaatcatggtcatagctgtttcct }\end{array}$ & This study \\
\hline around_pUC19_F & tcactcatggttatggcagcactgcataattc & This study \\
\hline around_pUC19_F & taacactgcggccaacttacttctgacaacg & This study \\
\hline 20bp_parS_BLI_probeF & [Biotin]GGGAtgTTTCACGTGAAAca & This study \\
\hline 20bp_parS_BLI_probeR & tgTTTCACGTGAAAcaTCCC & This study \\
\hline 28bp_tetO_BLI_probeF & [Biotin]ggggactctatcattgatagagtatgc & This study \\
\hline 28bp_tetO_BLI_probeR & gcatactctatcaatgatagagtcccc & This study \\
\hline 20bp_NBS_BLI_probeF & [Biotin]GGGAtaTTTCCCGGGAAAta & This study \\
\hline 20bp_NBS_BLI_probeR & taTTTCCCGGGAAAtaTCCC & This study \\
\hline
\end{tabular}

\section{Keys:}

M13F (-47): cgccagggtttcccagtcacgac M13R: aggaaacagctatgaccat

parS: tgtttcacgtgaaaca scrambled parS: aattacactgagttta

tetO: actctatcattgatagagt $\quad B a m H I R S:$ ggatcc EcoRI RS: gaattc 


\section{SUPPLEMENTARY REFERENCES}

1. Tran, N. T. et al. Permissive zones for the centromere-binding protein ParB on the Caulobacter crescentus chromosome. Nucleic Acids Res 46, 1196-1209 (2018).

2. Lim, H. C. et al. Evidence for a DNA-relay mechanism in ParABS-mediated chromosome segregation. Elife 3, e02758 (2014).

3. Jalal, A. S. B. et al. Evolving a new protein-DNA interface via sequential introduction of permissive and specificity-switching mutations. bioRxiv 724823 (2019) doi:10.1101/724823. 
A
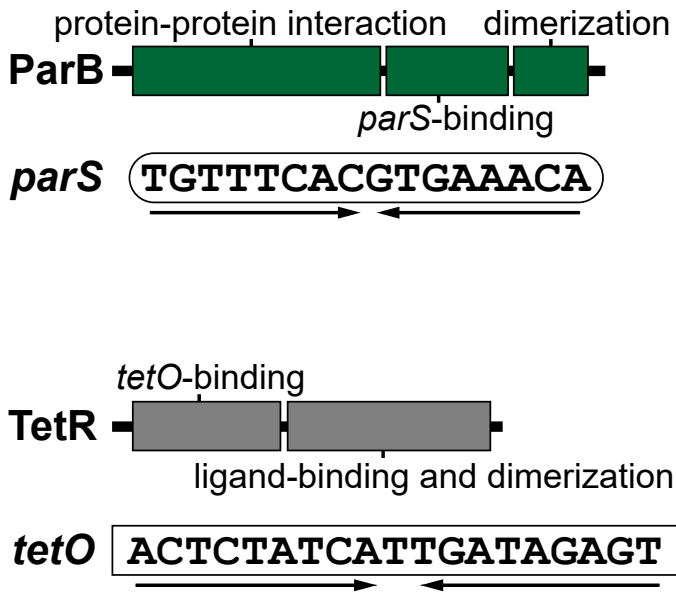

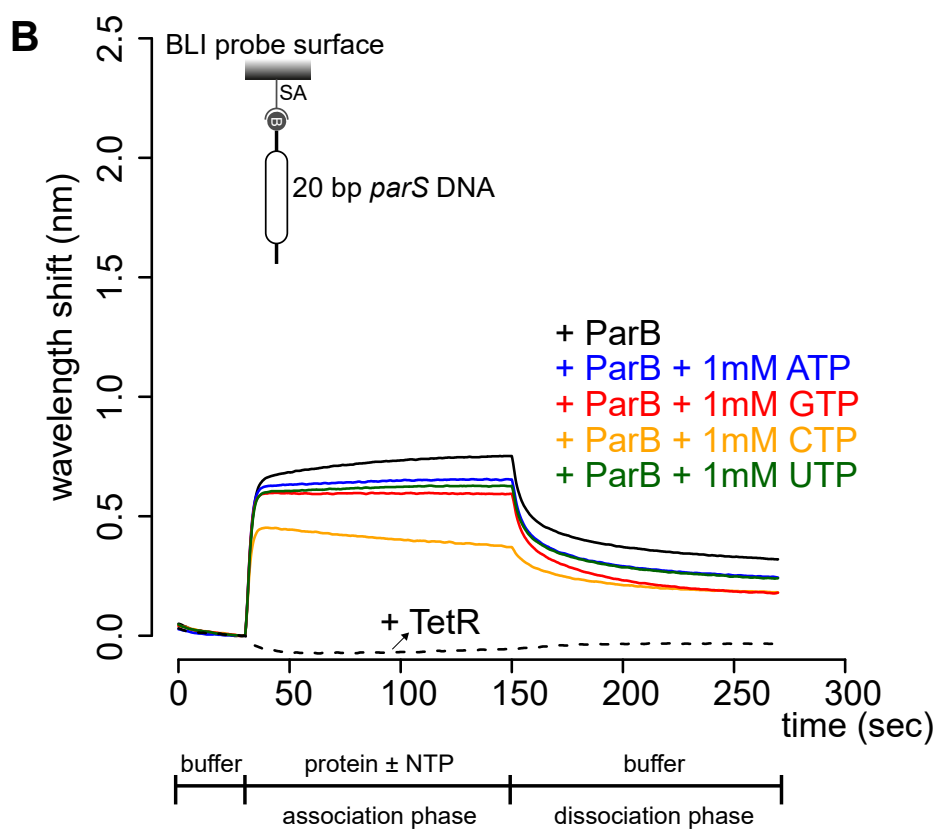

D

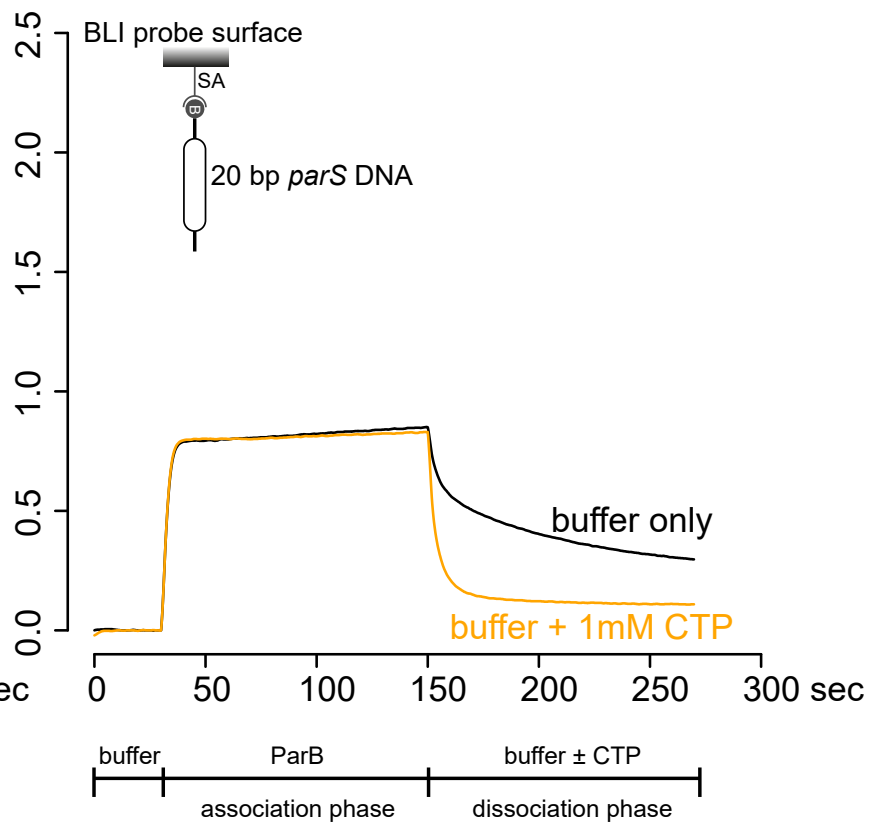

Figure 1. CTP reduces the nucleation of Caulobacter ParB at parS. (A) The domain architecture of ParB (dark green) and TetR (grey), and their respective DNA-binding sites parS and tetO. Convergent arrows below DNA-binding sites indicate that parS and tetO are palindromic. (B) Bio-layer interferometric (BLI) analysis of the interaction between a premix of $1 \mu \mathrm{M}$ ParB-His dimer $^{\prime} 1 \mathrm{mM}$ NTP and a 20-bp DNA duplex containing parS. Biotinylated DNA fragments were immobilized onto the surface of a Streptavidin (SA)-coated probe (See Materials and Methods). The BLI probe was dipped into a buffer only solution $(0-30 \mathrm{sec})$, then to a premix of protein \pm NTP $(30-150 \mathrm{sec}$ : association phase), and finally returned to a buffer only solution (150-270 sec: dissociation phase). Sensorgrams were recorded over time. BLI analysis of the interaction between $1 \mu \mathrm{M}$ TetR-His ${ }_{6}$ and a 20-bp parS probe was also recorded (a negative control). (C) BLI analysis of the interaction between a premix of $1 \mu \mathrm{M}$ TetR-His $_{6} \pm 1 \mathrm{mM} \mathrm{NTP}$ and a 28-bp DNA duplex containing tetO. BLI analysis of the interaction between $1 \mathrm{mM}$ CTP and a 28-bp tetO probe was also recorded (a negative control). (D) BLI analysis of the interaction between $1 \mu \mathrm{M}$ Caulobacter ParB-His 6 (without CTP) and a 20-bp parS DNA. For the dissociation phase, the probe was returned to a buffer only or buffer supplemented with $1 \mathrm{mM} \mathrm{CTP}$. All buffers used for experiments in this figure contained $\mathrm{Mg}^{2+}$. Each $\mathrm{BLI}$ experiment was triplicated and a representative sensorgram was presented. 

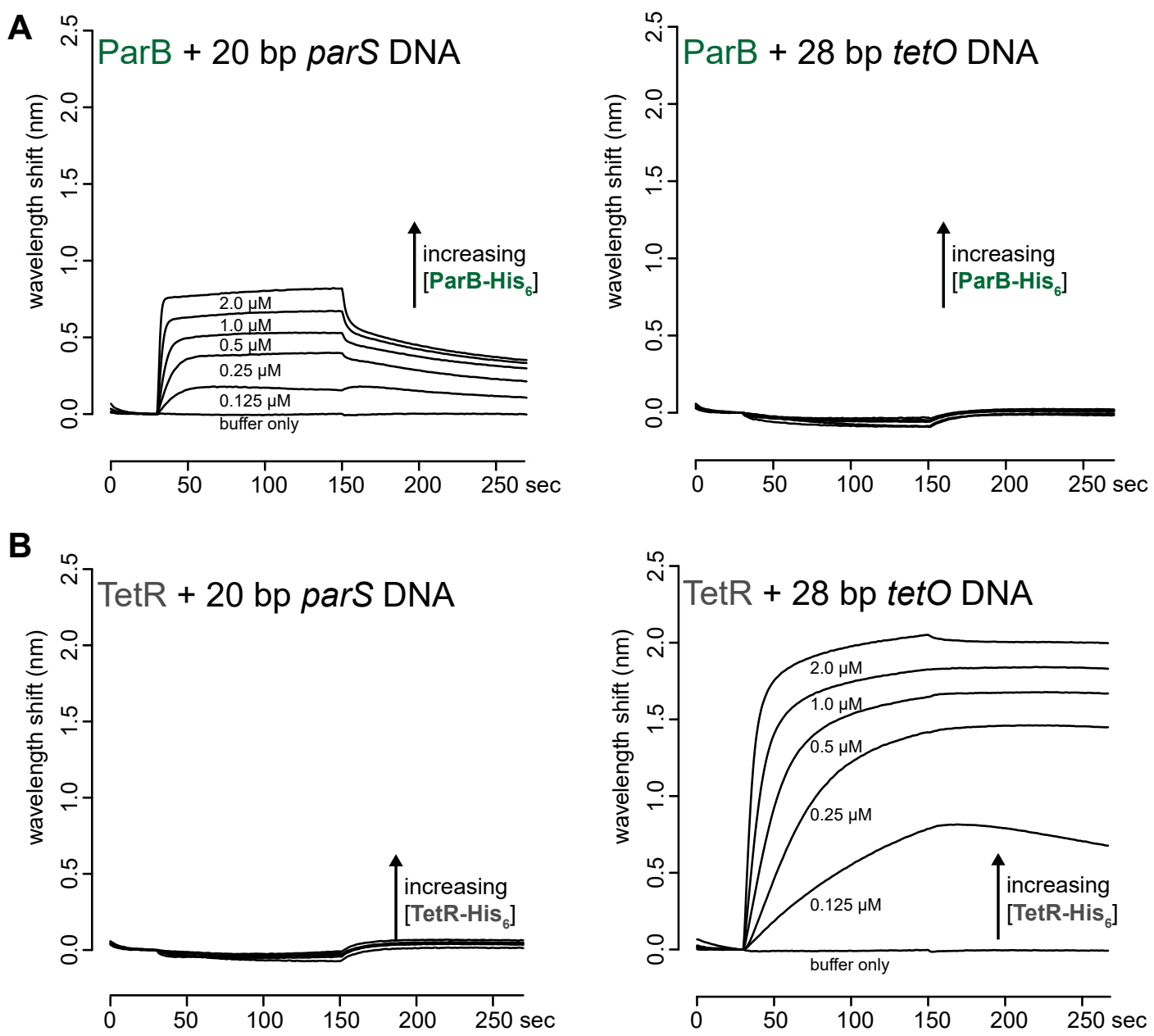

Figure 1-figure supplement 1. ParB and TetR bind specifically to their cognate binding sites parS and tetO, respectively. (A) BLI analysis of the interaction between purified Caulobacter ParB-His 6 $(0.125$ to $2 \mu \mathrm{M})$ and a 20 -bp parS DNA probe or a 28-bp tetO DNA probe. (B) BLI analysis of the interaction between purified TetR-His $6(0.125$ to $2 \mu \mathrm{M})$ and a 20-bp parS DNA probe or a 28-bp tetO DNA probe. 


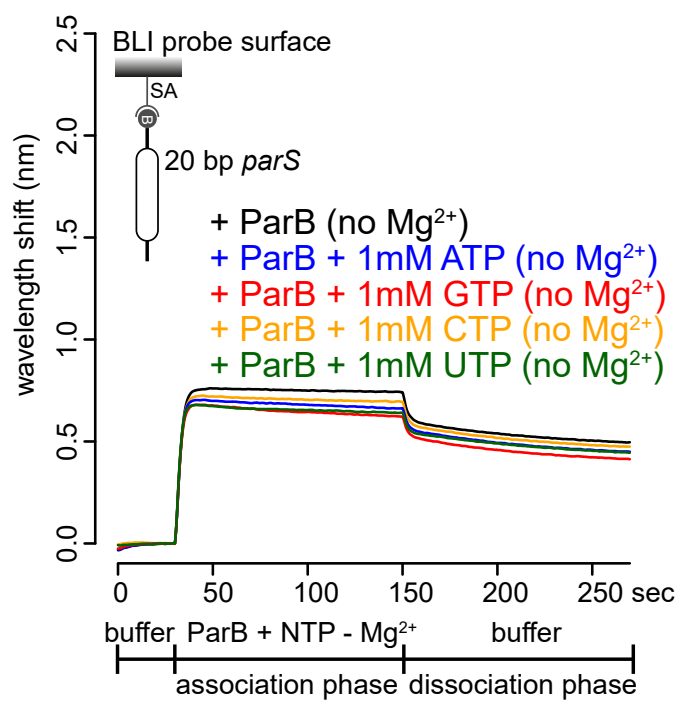

Figure 1-figure supplement 2. BLI analysis of the interaction between purified Caulobacter ParB and NTP in buffers lacking $\mathbf{M g}^{2+}$. Caulobacter ParB-His ${ }_{6}(1 \mu \mathrm{M}$ dimer $) \pm 1 \mathrm{mM}$ NTP, and a 20-bp DNA duplex containing parS were used. $\mathrm{Mg}^{2+}$ was omitted from all buffers in this experiment. A schematic of the DNA substrate is shown above the sensorgram. 

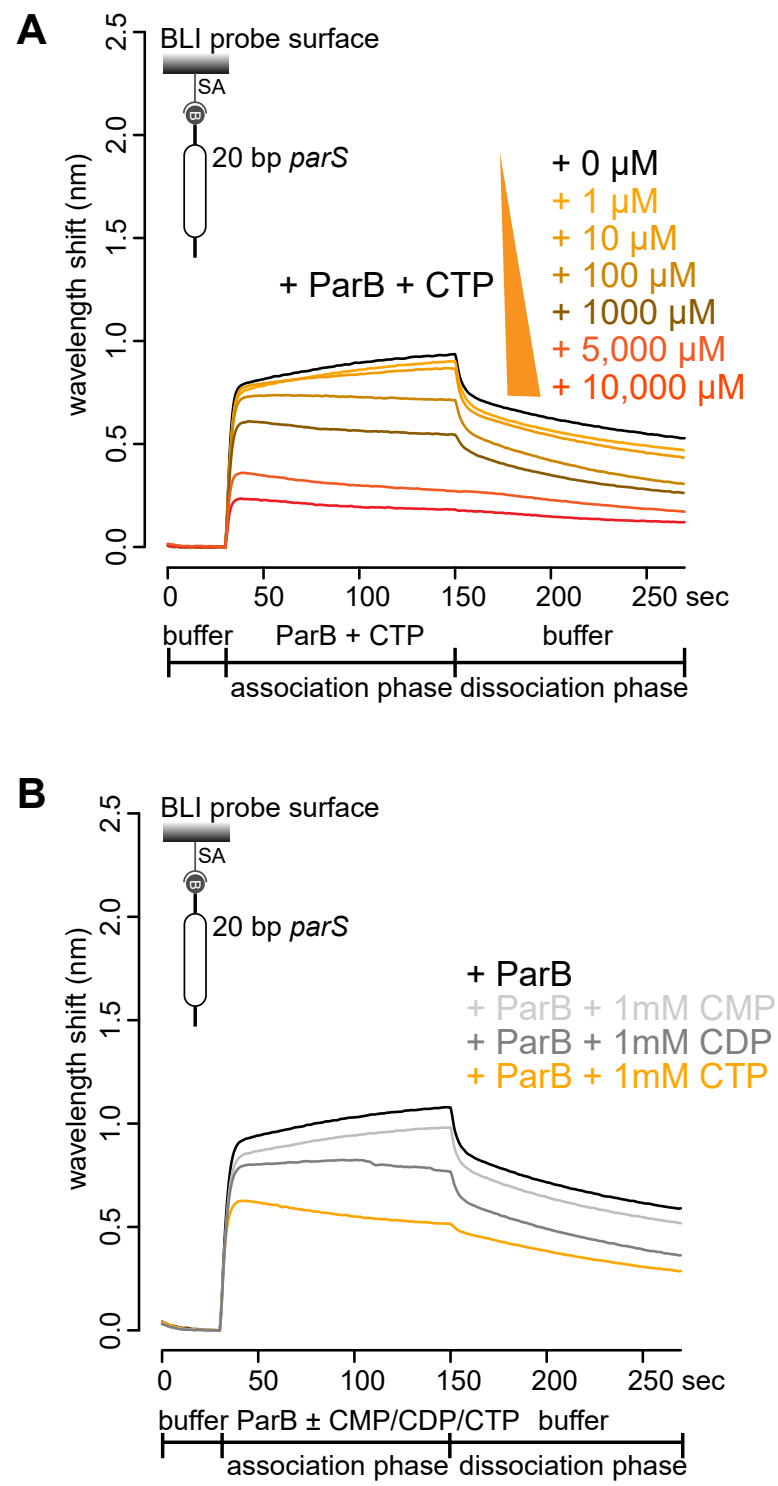

Figure 1-figure supplement 3. BLI analysis of the interaction between purified Caulobacter ParB and cytidine mono-, di-, or triphosphate. (A) BLI analysis of the interaction between purified Caulobacter ParB and an increasing concentration of CTP-Mg ${ }^{2+}$. ParB-His 6 (1 $\mu \mathrm{M}$ dimer) $+0-10 \mathrm{mM}$ CTP, and a 20-bp DNA duplex containing parS were used for this experiment. (B) BLI analysis of the interaction between a premix of $1 \mu \mathrm{M}$ Caulobacter ParB-His ${ }_{6} \pm 1 \mathrm{mM}$ cytidine mono-, di-, or triphosphate, and a 20-bp parS DNA. A schematic of the DNA substrate is shown above the sensorgram. $\mathrm{Mg}^{2+}$ was included in all buffers for experiments in this figure. 
A

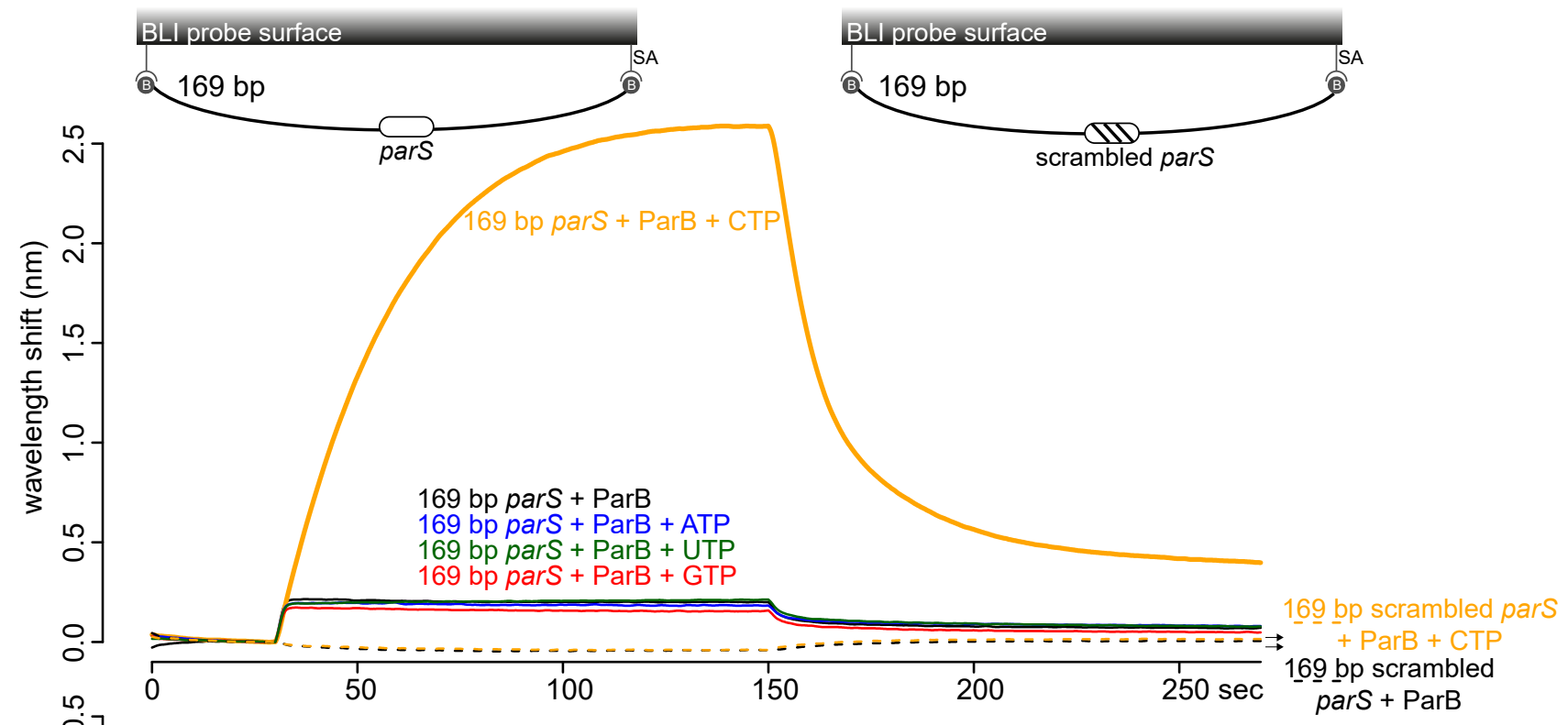

B

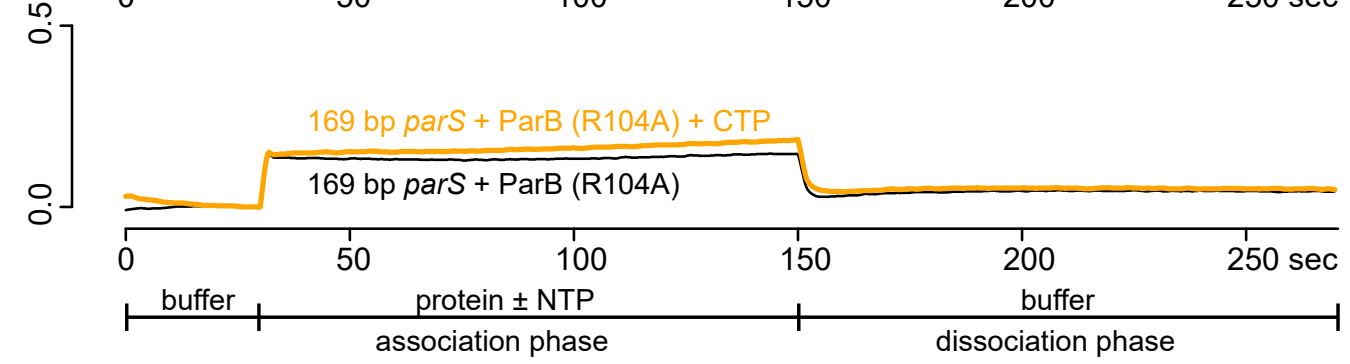

C
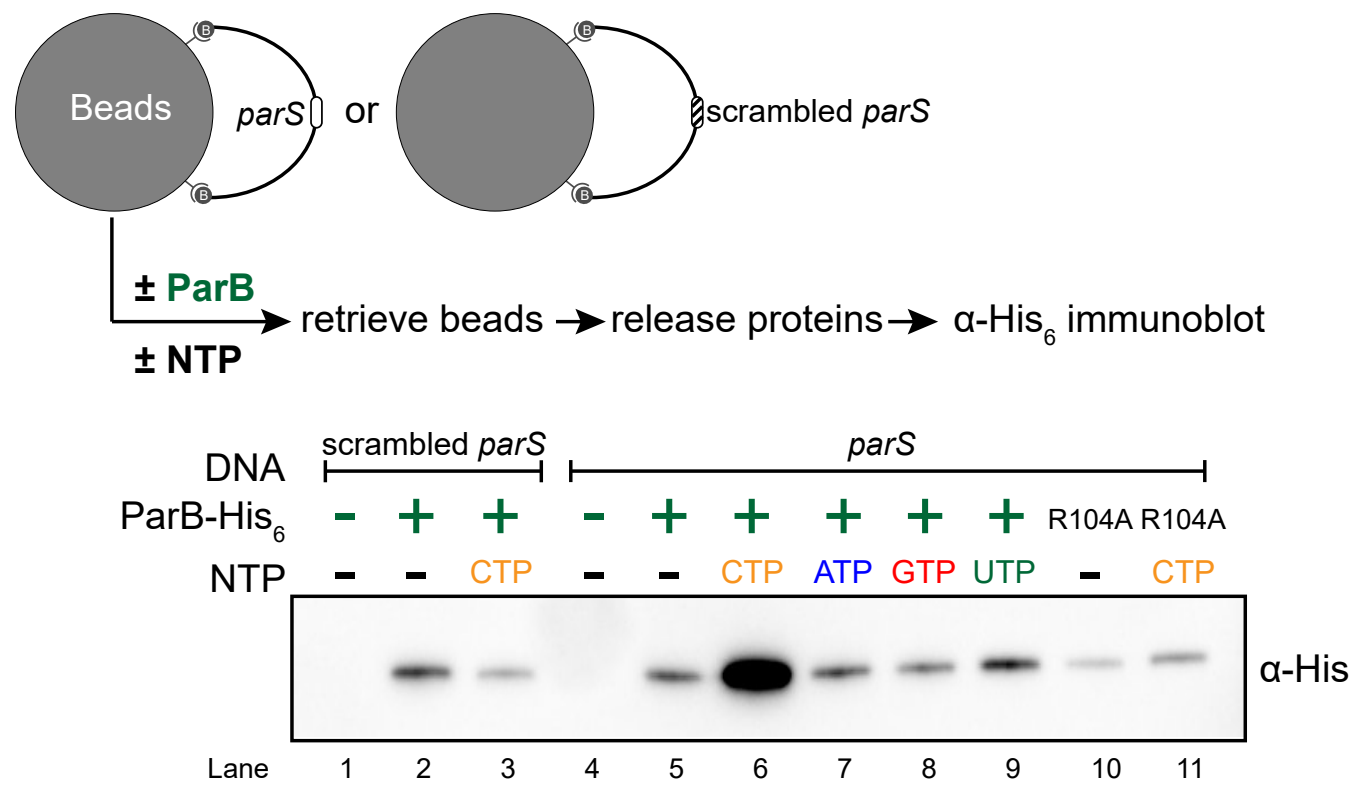

Figure 2. CTP facilitates ParB association with a closed DNA substrate beyond nucleation. (A) $\mathrm{BLI}$ analysis of the interaction between a premix of $1 \mu \mathrm{M}$ Caulobacter ParB-His ${ }_{6} \pm 1 \mathrm{mM}$ NTP and a 169-bp dual biotin-labeled DNA containing a parS or a scrambled parS site. Interactions between a dual biotinylated DNA and streptavidin (SA)-coated probe created a DNA substrate where both ends were blocked (a closed DNA substrate) (see the schematic of the BLI probes above the sensorgram). (B) Interactions between a nucleation-competent but spreading-defective ParB (R104) variant with a 169bp parS DNA fragment in the presence or absence of CTP were also recorded. Each BLI experiment was triplicated and a representative sensorgram was presented. (C) A schematic of the pull-down assay and immunoblot analysis of pulled-down Caulobacter ParB-His 6 . The length of bound DNA is $\sim 2.8 \mathrm{~kb}$. Beads were incubated with ParB protein for five minutes before being pulled down magnetically. All buffers used for experiments in this figure contained $\mathrm{Mg}^{2+}$. 
A

dual biotin-labeled 169 bp parS single biotin-labeled 169 bp parS

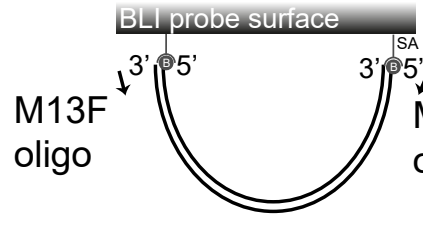

PCR product: yes

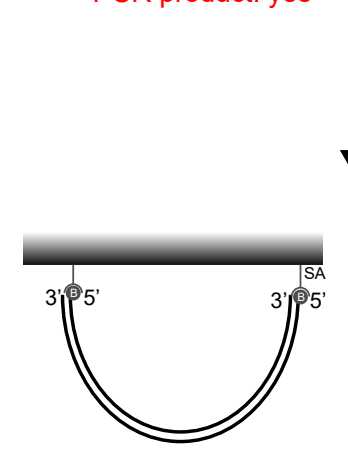

PCR product: yes

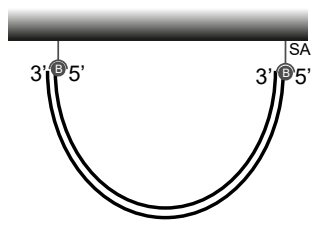

PCR product: yes

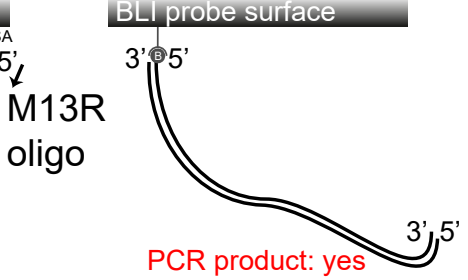

Exonuclease T7

polarity: 5' to 3'

no activity on SsDNA

activity on dsDNA unless 5' DNA ends are blocked by SA-biotin interaction

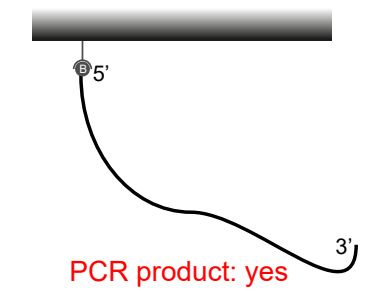

Exonuclease VII

polarity: 5' to 3' and 3' to 5'

no activity on dsDNA

activity on ssDNA

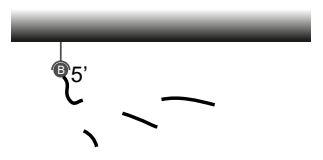

PCR product: no
B

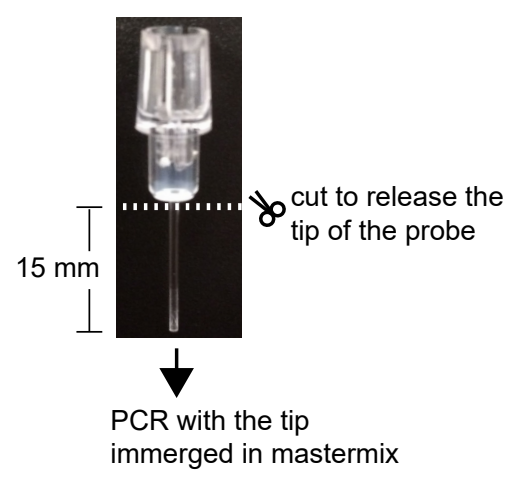

C
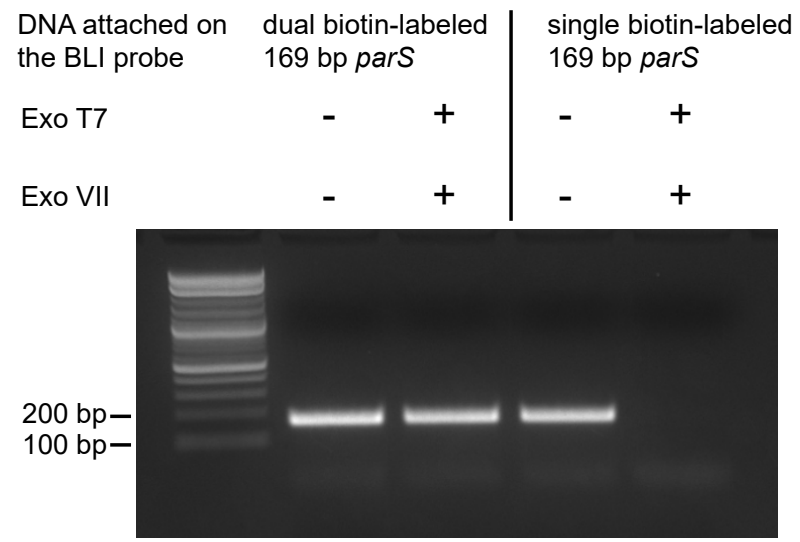

10 PCR cycles

Figure 2-figure supplement 1. Dual biotin-labeled DNA fragments form a closed substrate on the surface of the BLI probe. (A) A schematic of a double digestion assay using Exonuclease T7 + Exonuclease VII and PCR. PCR was performed using M13F, M13R oligos, and DNA attached to the $B L I$ surface as a template. (B) The BLI probe was severed from the plastic adaptor and immerged into a PCR master mix. (C) Dual biotin-labeled DNA fragments on the BLI surface were resistant to Exo T7 + Exo VII digestion while single biotin-labeled DNA fragments on the BLI surface were not. 
A

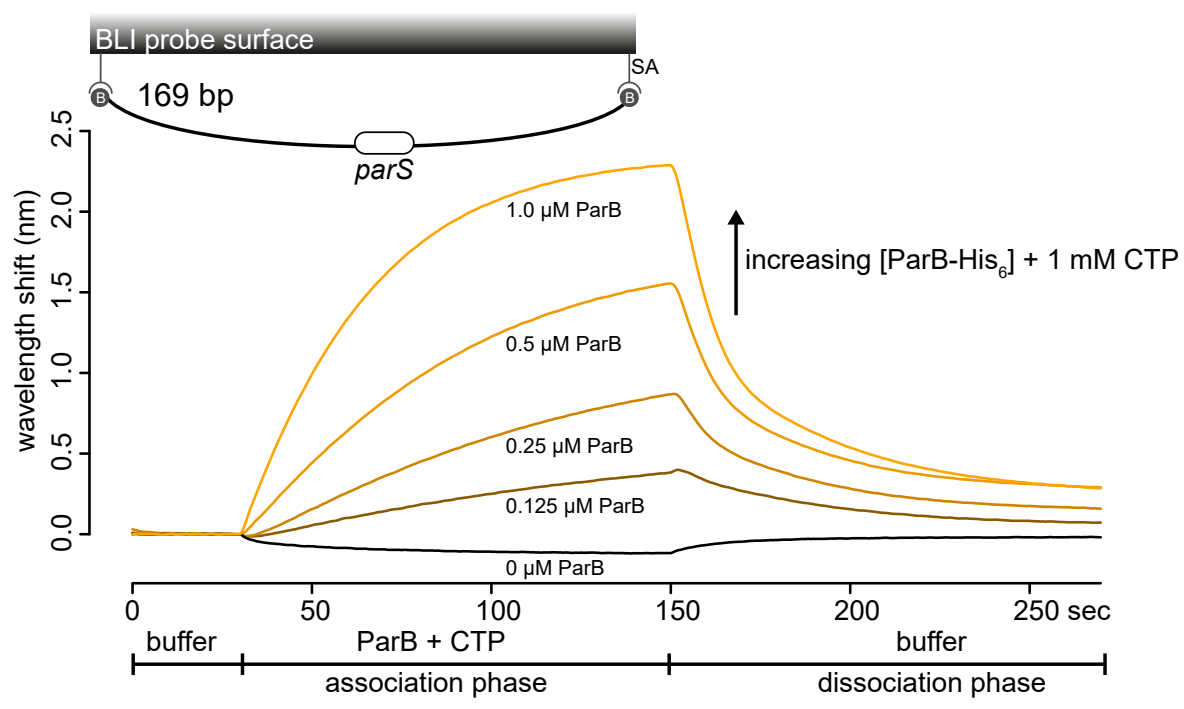

B

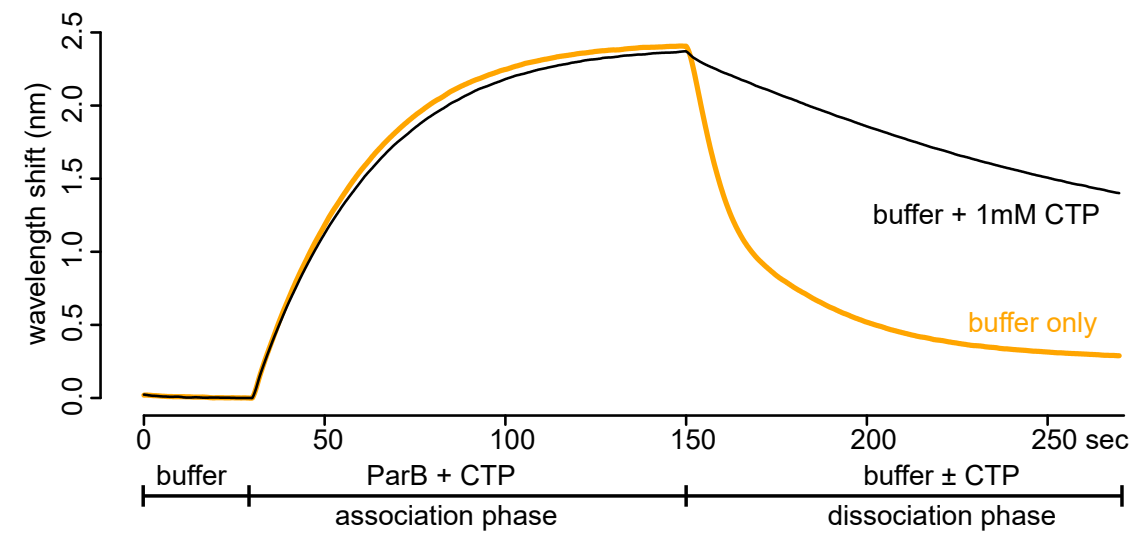

C

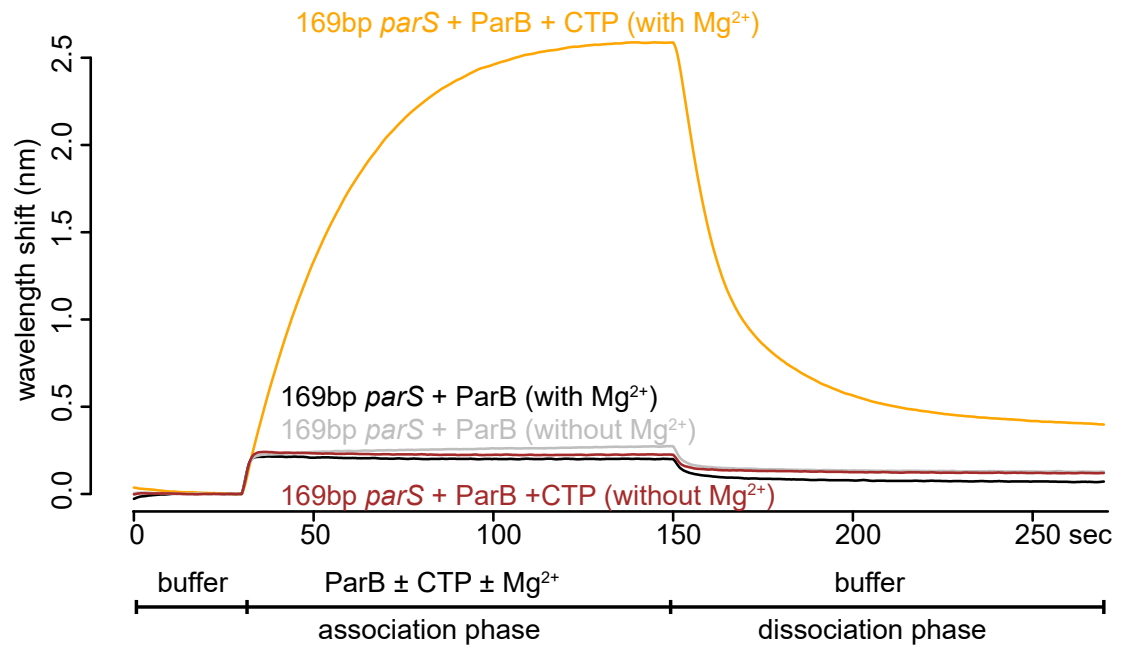

Figure 2-figure supplement 2. CTP-Mg ${ }^{2+}$ enhances ParB accumulation on a closed DNA substrate. (A) BLI analysis of the interaction between an increasing concentration of Caulobacter ParBHis $_{6}(0.125$ to $1.0 \mu \mathrm{M})+1 \mathrm{mM}$ CTP and a $169-\mathrm{bp}$ dual biotin-labeled parS DNA. A schematic of the DNA substrate is shown above the sensorgram. (B) BLI analysis of the interaction between $1 \mu \mathrm{M}$ Caulobacter ParB-His 6 (with $1 \mathrm{mM} \mathrm{CTP)}$ ) and a 169-bp dual biotin-labeled parS DNA. For the dissociation phase, the probe was returned to a buffer only or buffer supplemented with $1 \mathrm{mM} \mathrm{CTP}$ solution. All buffers used for experiments in panel A-B contained $\mathrm{Mg}^{2+}$. (C) BLI analysis of the interaction between a premix of $1 \mu \mathrm{M}$ Caulobacter ParB-His ${ }_{6} \pm 1 \mathrm{mM}$ CTP and a 169-bp dual biotin-labeled DNA containing a parS site in buffer with or without $\mathrm{MgCl}_{2}$. 

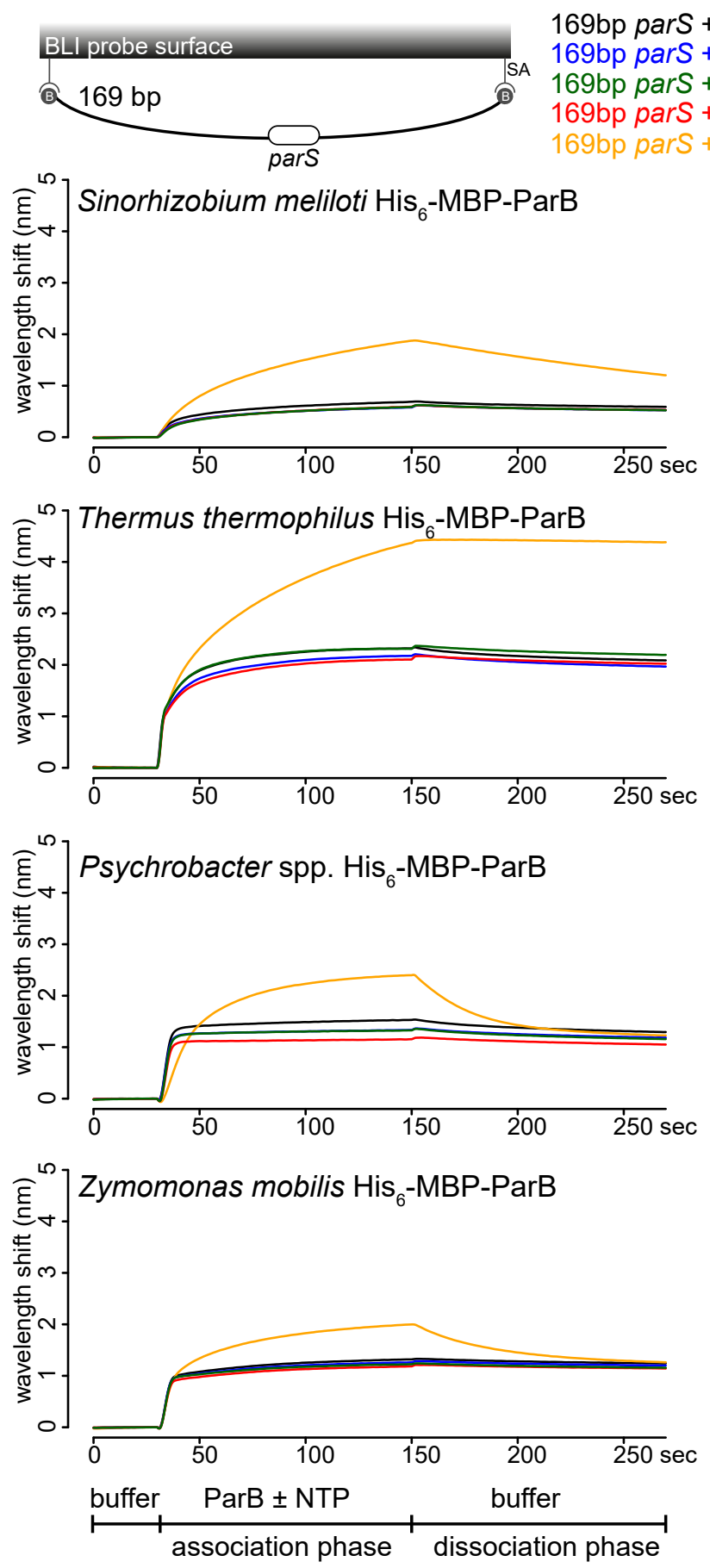

169bp pars + ParB

$169 \mathrm{bp}$ parS + ParB + ATP

$169 \mathrm{bp}$ parS + ParB + UTP

$169 \mathrm{bp}$ parS + ParB + GTP
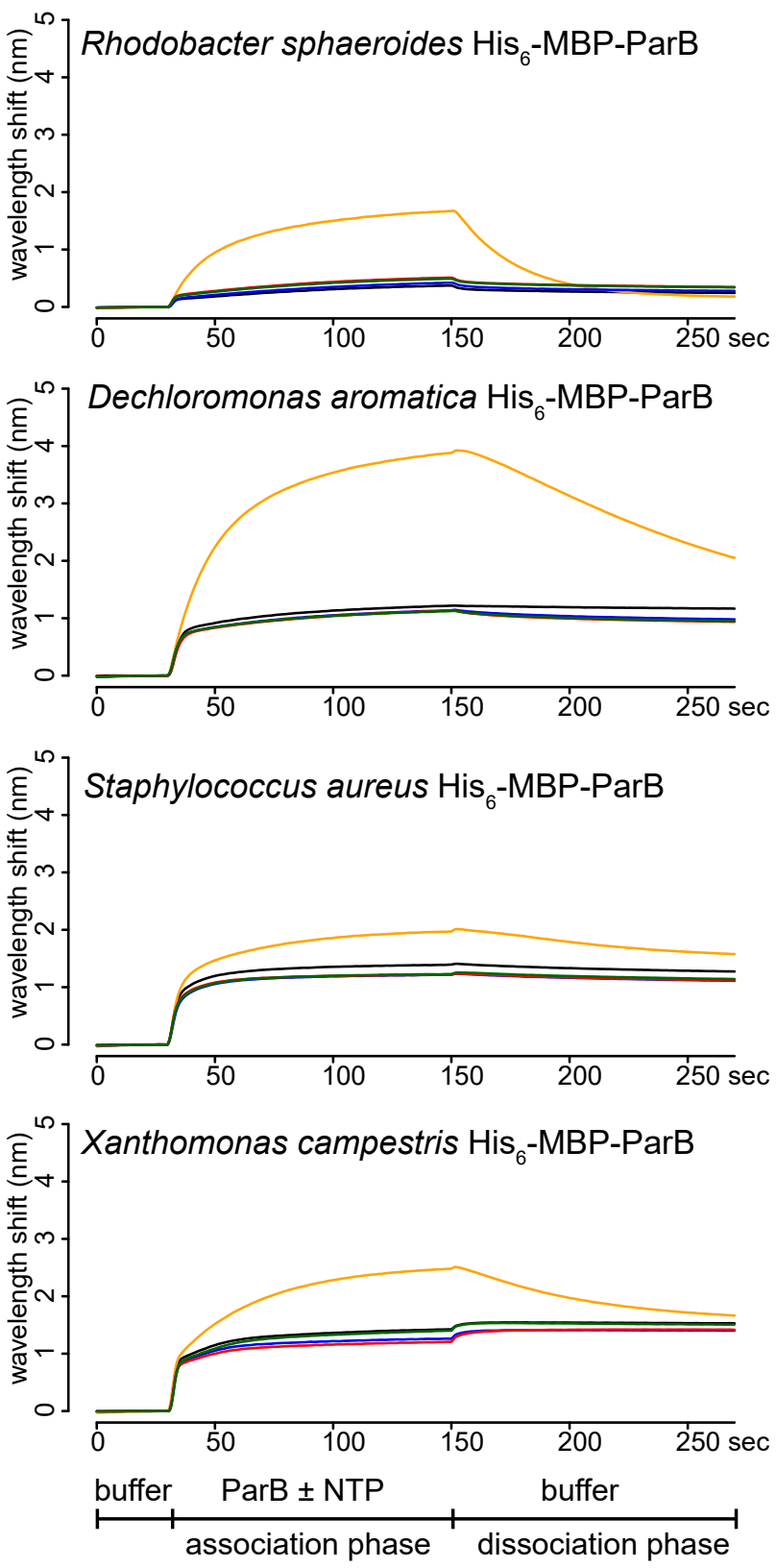

Figure 2-figure supplement 3. CTP facilitates the association of eight ParB orthologs with DNA. $\mathrm{BLI}$ analysis of the interaction between a premix of $1 \mu \mathrm{M}$ His 6 -MBP-tagged ParB proteins from a set of diverse bacterial species \pm NTPs and a 169-bp dual biotin-labeled parS DNA. NTPs at $1 \mathrm{mM}$ (final concentration) was used, except for BLI experiments with Zymomonas mobilis and Xanthomonas campestris ParBs where $0.01 \mathrm{mM}$ CTP was used instead. $\mathrm{Mg}^{2+}$ was included in all buffers for this experiment. A schematic of the DNA substrate is shown above the sensorgrams. 
A

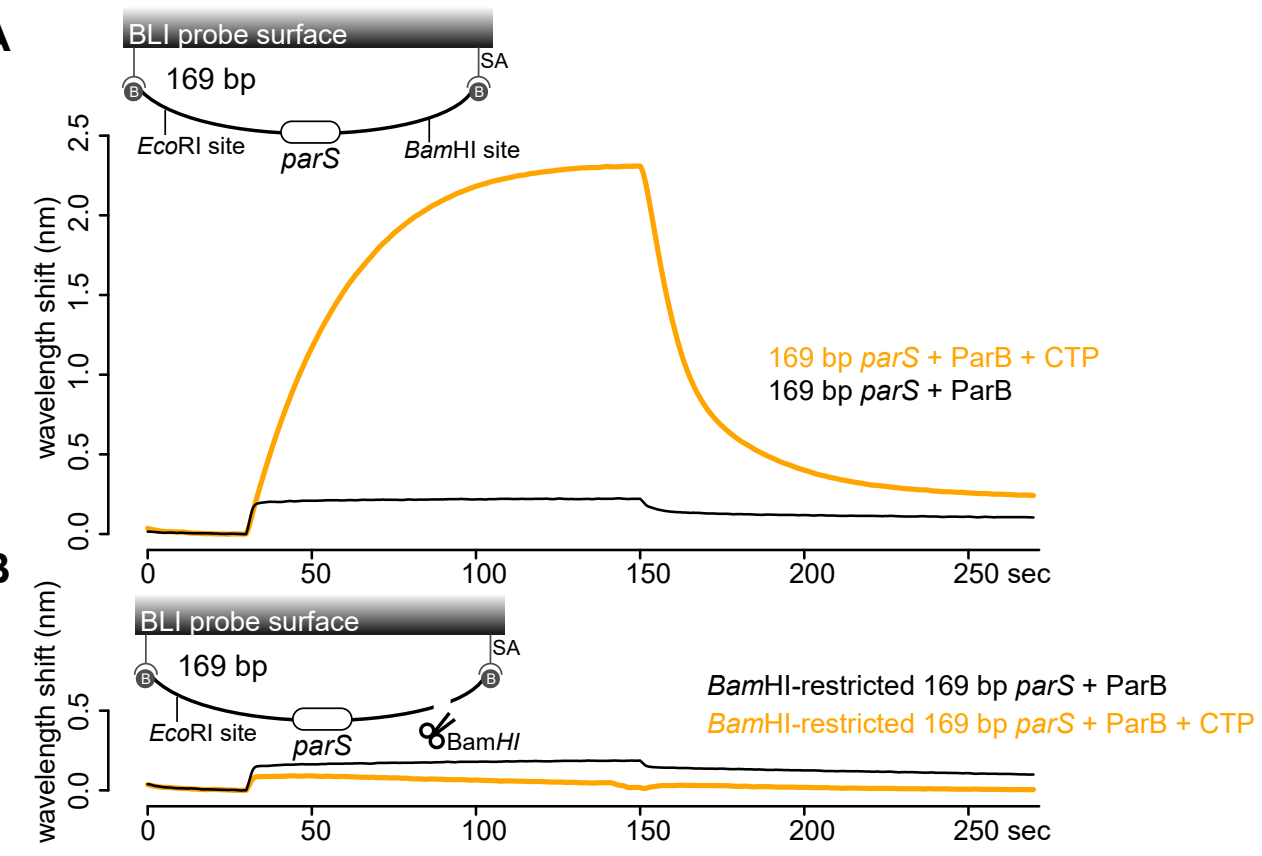

C

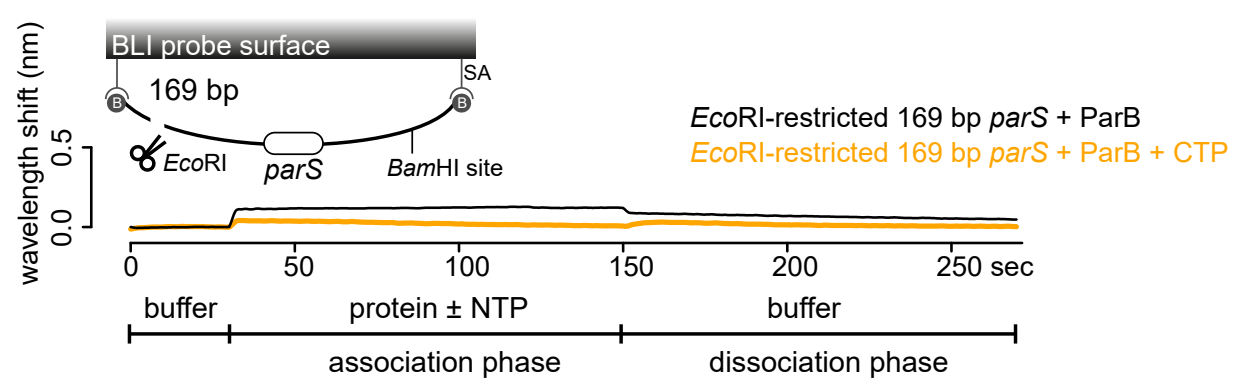

D

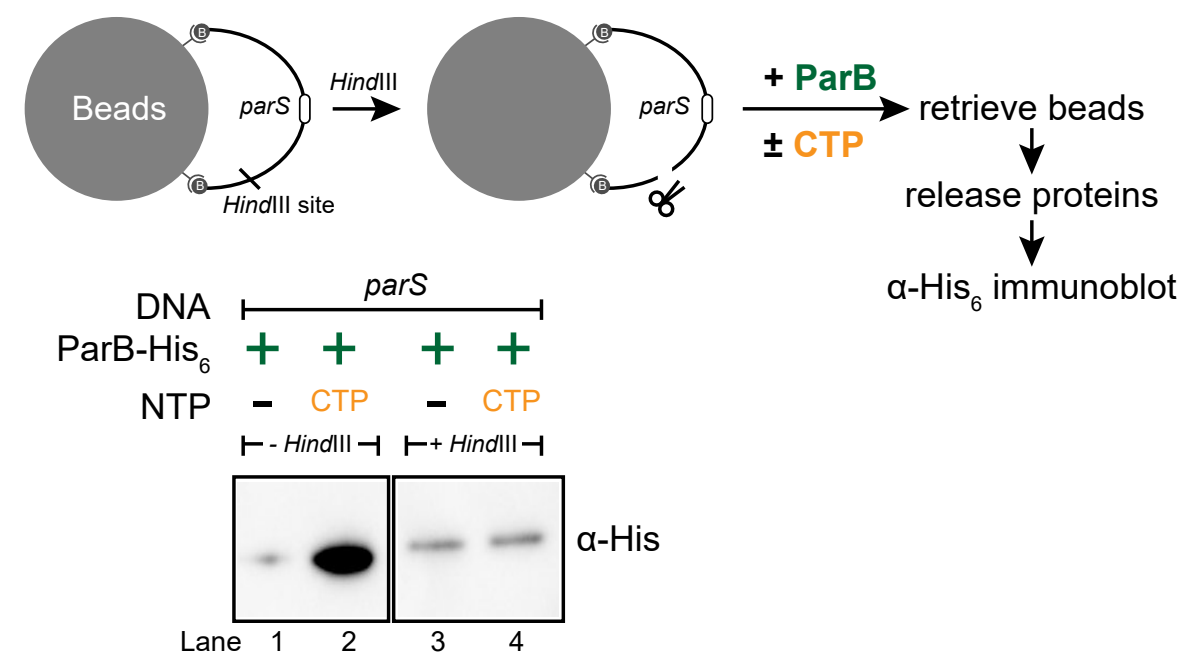

Figure 3. A closed DNA substrate is required for an increased association of ParB with DNA. (A) $\mathrm{BLI}$ analysis of the interaction between a premix of $1 \mu \mathrm{M}$ Caulobacter ParB-His ${ }_{6} \pm 1 \mathrm{mM}$ CTP and a 169bp dual biotin-labeled parS DNA. (B) Same as panel A but immobilized DNA fragments have been restricted with BamHI before BLI analysis. (C) Same as panel A but immobilized DNA fragments have been restricted with EcoRI before BLI analysis. Schematic of DNA fragments with the relative positions of parS and restriction enzyme recognition sites are shown above the sensorgram. Each BLI experiment was triplicated and a representative sensorgram was presented. (D) A schematic of the pull-down assay and immunoblot analysis of pulled-down Caulobacter ParB-His. For lanes 3 and 4, DNA-bound beads were incubated with HindIII to linearize bound DNA. Samples in lanes 1-4 were loaded on the same gel, the immunoblot was spliced together for presentation purposes. All buffers used for experiments in this figure contained $\mathrm{Mg}^{2+}$. 
A

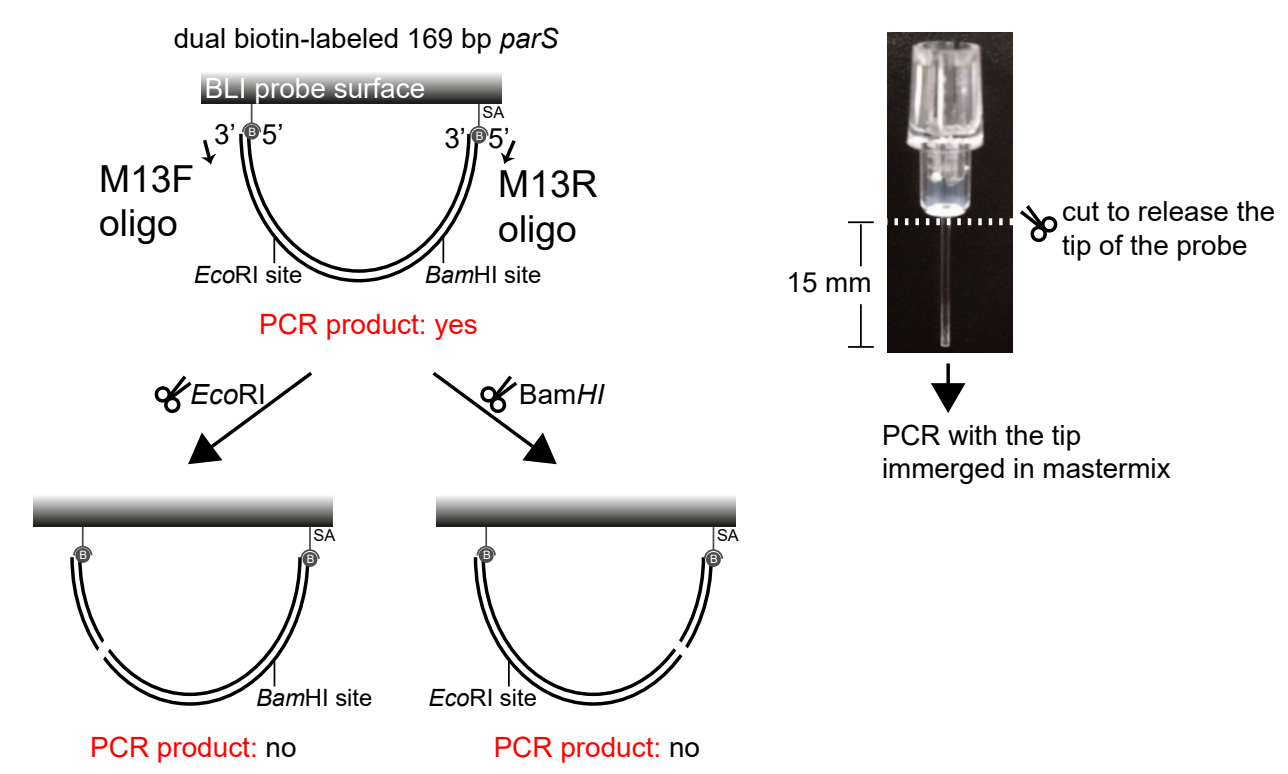

B

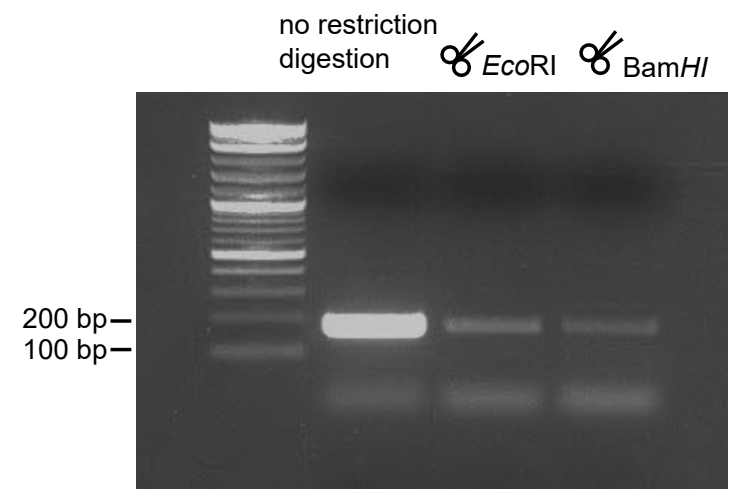

10 PCR cycles

Figure 3-figure supplement 1. Restriction enzymes linearize dual biotin-labeled DNA fragments on the surface of the BLI probe. (A) (Left panel) A schematic of a digestion assay using BamHI/EcoRI and PCR. PCR was performed using M13F, M13R oligos, and DNA attached to the BLI surface as a template. (Right panel) The BLI probe was severed from the plastic adaptor and immerged into a PCR master mix. (B) Detection of intact 169-bp DNA fragments that were bound on the surface of the BLI probe before and after treatment with restriction enzymes. 

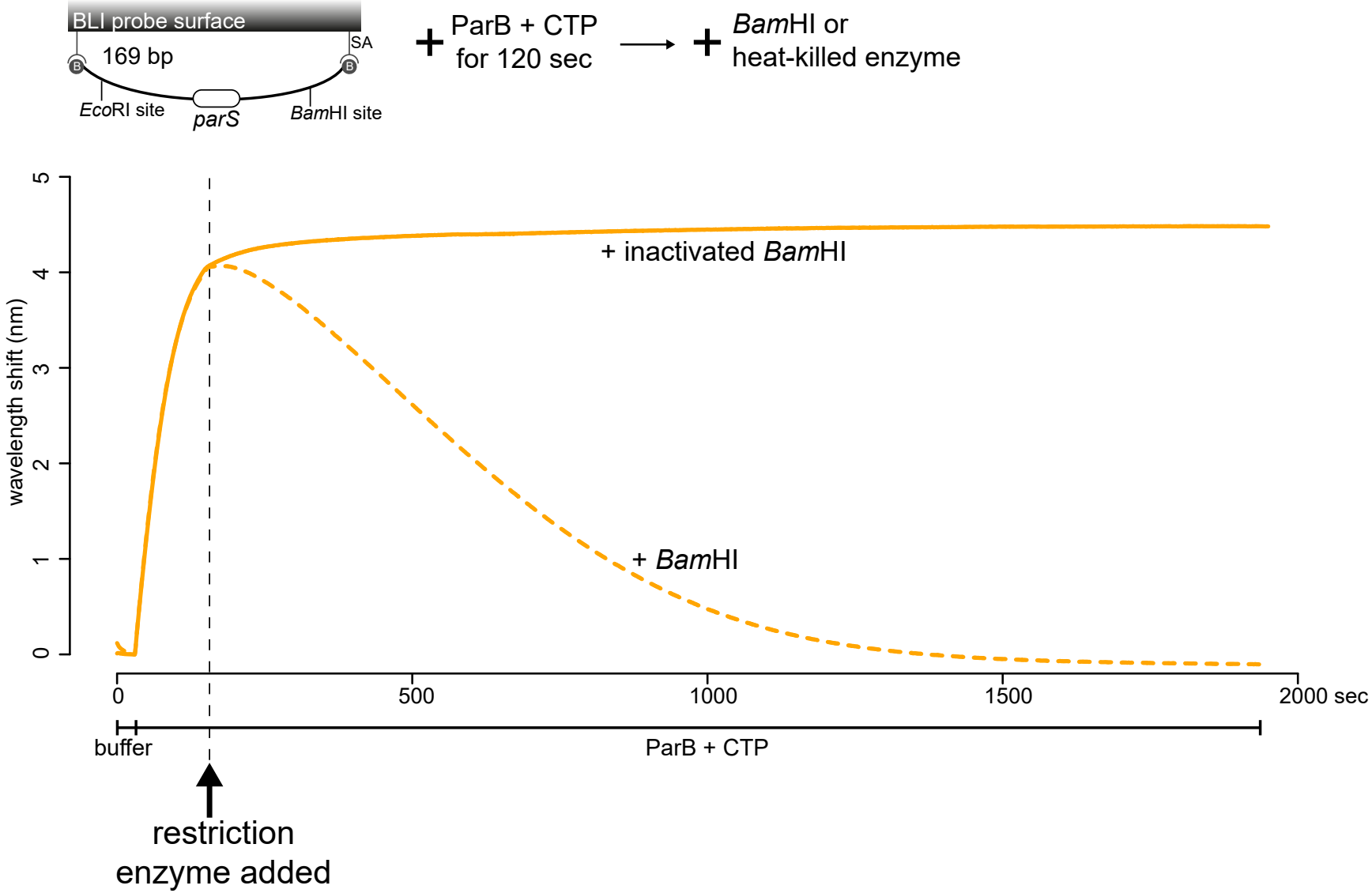

Figure 3-figure supplement 2. Linearization of a closed DNA substrate by BamHI liberates prebound ParB from DNA. BamHI was added after $1 \mu \mathrm{M}$ Caulobacter ParB-His ${ }_{6}+1 \mathrm{mM}$ CTP and a 169bp dual biotin-labeled parS DNA were preincubated together for $120 \mathrm{sec}$. As a negative control, heatinactivated $\mathrm{BamHI}$ was added instead. $\mathrm{Mg}^{2+}$ was included in all buffers for this experiment. A schematic of the DNA substrate is shown above the sensorgram. 

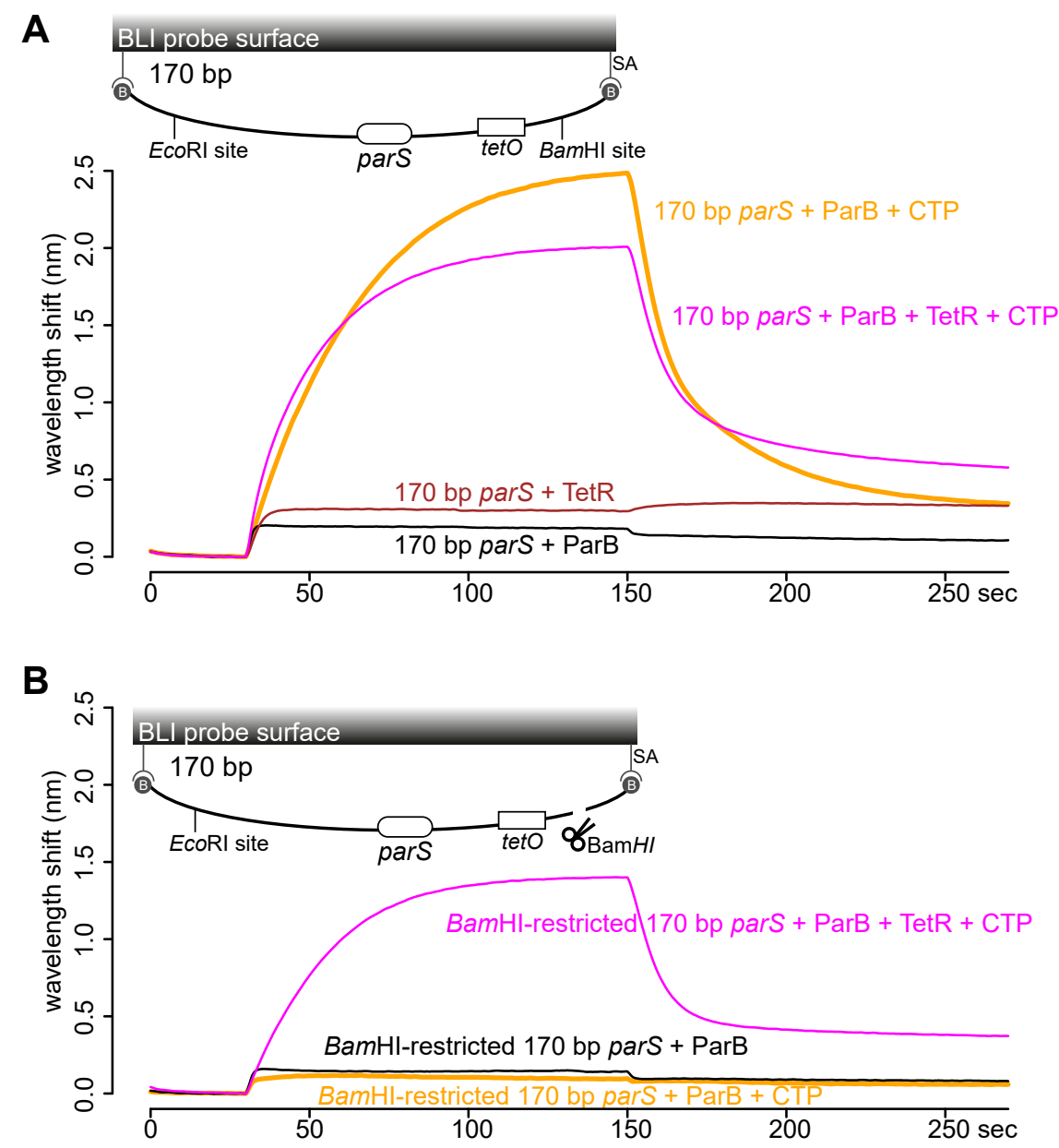

C

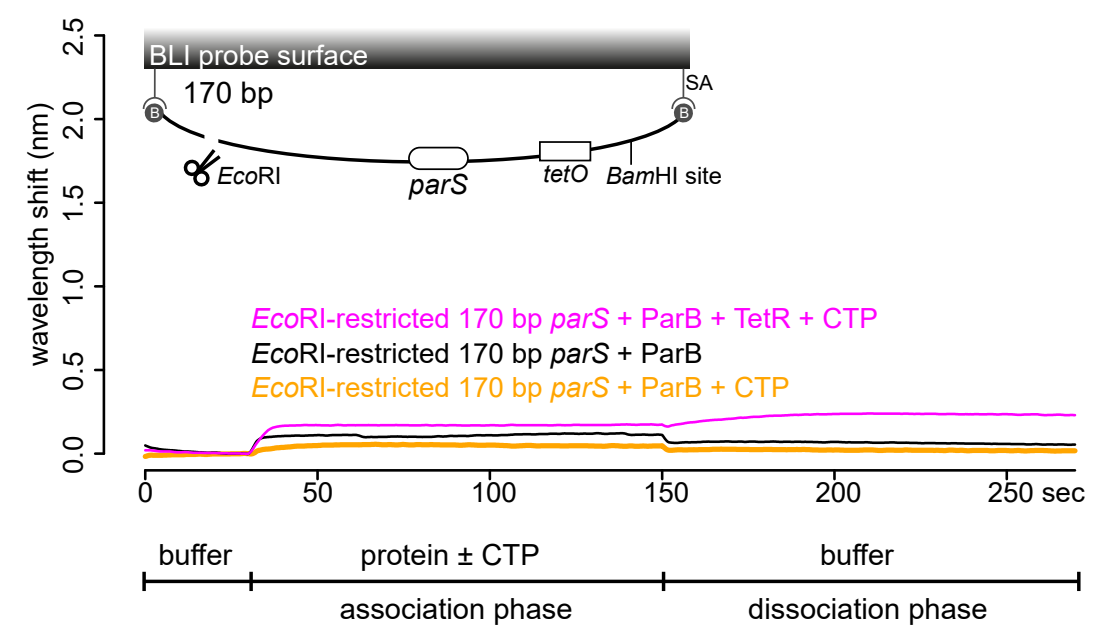

Figure 4. TetR-tetO binding restores ParB association with an opened DNA substrate. (A) BLI analysis of the interaction between a premix of $1 \mu \mathrm{M}$ Caulobacter ParB-His ${ }_{6} \pm 1 \mathrm{mM}$ CTP $\pm 1 \mu \mathrm{M}$ TetRHis $_{6}$ and a 170-bp dual biotin-labeled DNA containing a parS site. (B) Same as panel A but immobilized DNA fragments have been restricted with BamHI before BLI analysis. (C) Same as panel A but immobilized DNA fragments have been restricted with EcoRI before BLI analysis. Schematic of DNA fragments together with the relative positions of parS, tetO, and restriction enzyme recognition sites are shown above the sensorgram. Each BLI experiment was triplicated and a representative sensorgram was presented. All buffers used for experiments in this figure contained $\mathrm{Mg}^{2+}$. 

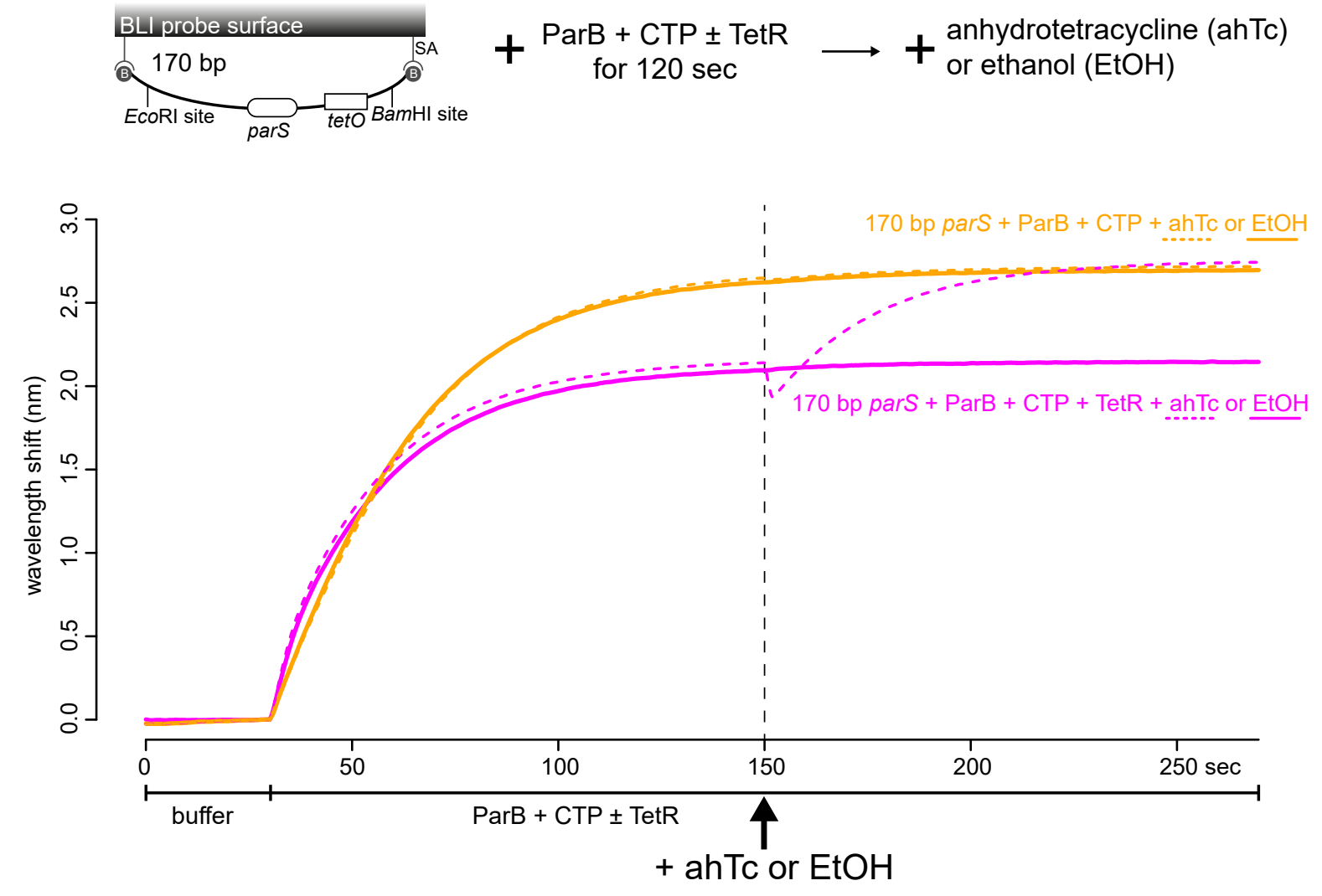

Figure 4-figure supplement 1. Anhydrotetracycline removes DNA-bound TetR roadblock and allows ParB to accumulate further on DNA. Anhydrotetracycline $(3 \mu \mathrm{M})$ or ethanol $(0.01 \%)$ was added after $1 \mu \mathrm{M}$ Caulobacter ParB-His ${ }_{6}+1 \mathrm{mM}$ CTP $\pm 1 \mu \mathrm{M}$ TetR and a 170-bp dual biotin-labeled parS DNA were preincubated together for $120 \mathrm{sec}$. $\mathrm{Mg}^{2+}$ was included in all buffers for this experiment. A schematic of the DNA substrate is shown above the sensorgram. 
A

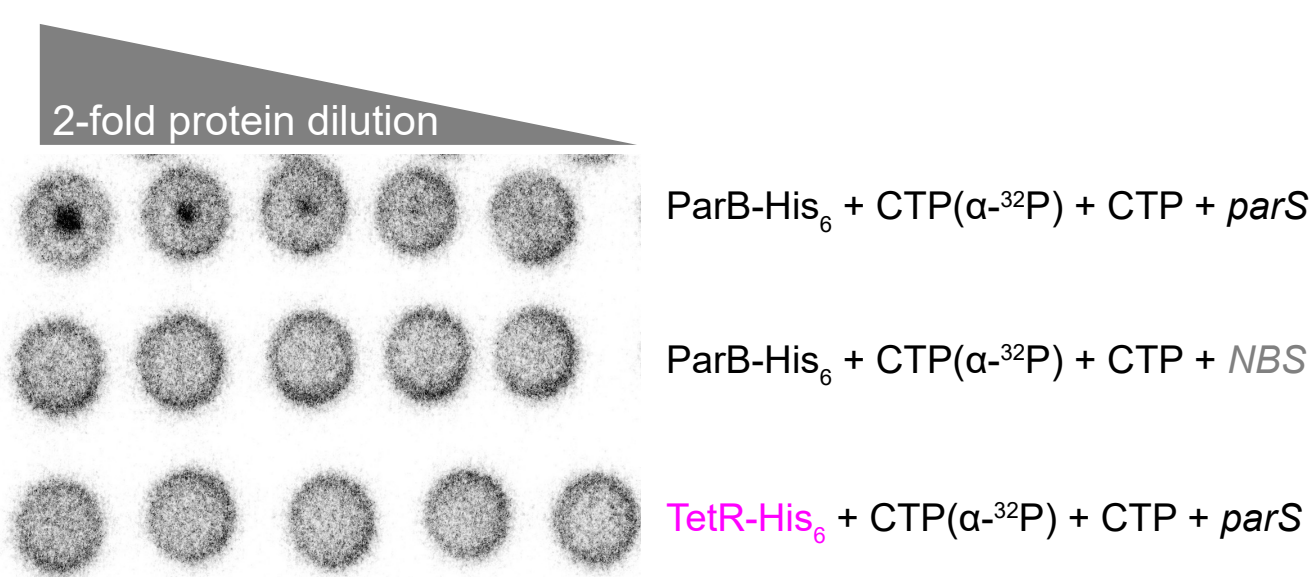

B

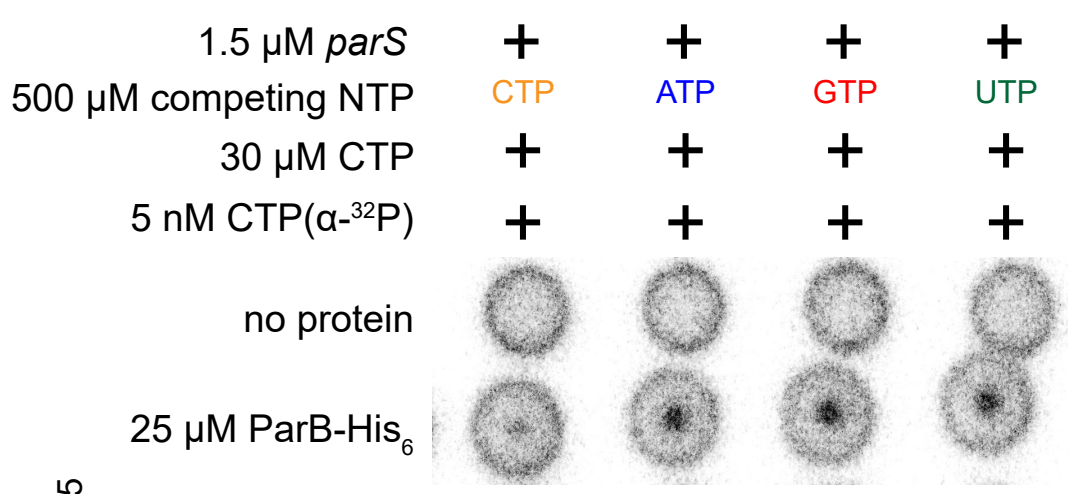

C

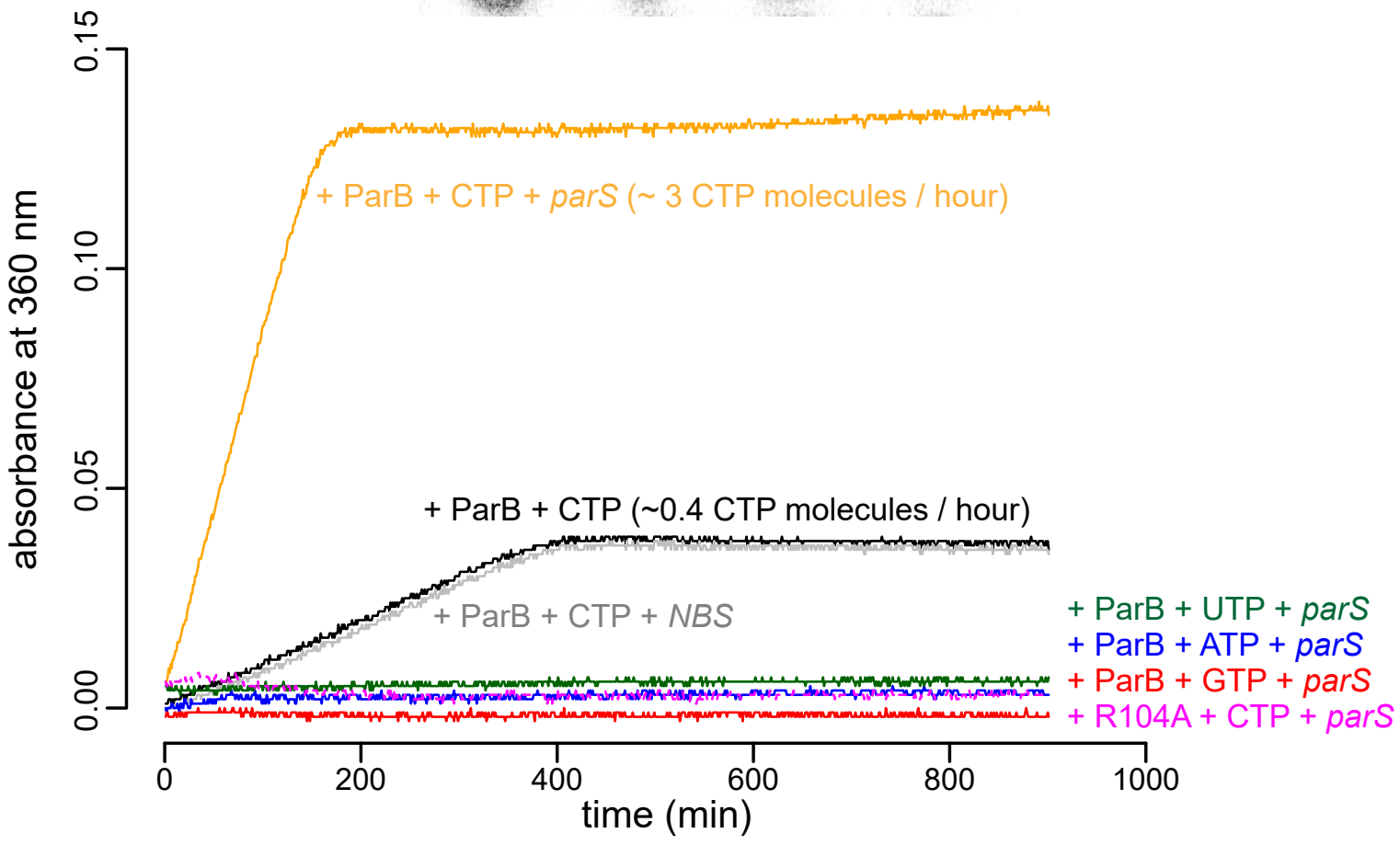

Figure 5. parS DNA increases the CTP binding and hydrolysis rate by Caulobacter ParB. (A-B) CTP binding as monitored by DRaCALA assay using radiolabeled CTP $\alpha-P^{32}$. The bulls-eye staining indicates CTP binding due to a more rapid immobilization of protein-ligand complexes compared to free ligands alone. The starting concentration of proteins used in panel A was $25 \mu \mathrm{M}$. The same concentration of radioactive CTP, unlabeled CTP, and DNA was used in experiments shown in panels $\mathrm{A}$ and $\mathrm{B}$. (C) A continuous monitoring of inorganic phosphate $(\mathrm{Pi})$ released by recording absorbance at $360 \mathrm{~nm}$ overtime at $25^{\circ} \mathrm{C}$. The rates of CTP hydrolysis were inferred from a Pi standard. The NTP hydrolysis of Caulobacter ParB was also monitored in the presence of ATP, GTP, or UTP, with a 22-bp parS DNA duplex or a non-cognate 22-bp NBS DNA duplex (a DNA-binding site of Noc protein (Wu and Errington, 2004)). The nucleation-competent but spreading-defective ParB (R104A) mutant did not hydrolyze CTP in the presence of parS DNA. All buffers used for experiments in this figure contained $\mathrm{Mg}^{2+}$. 
A
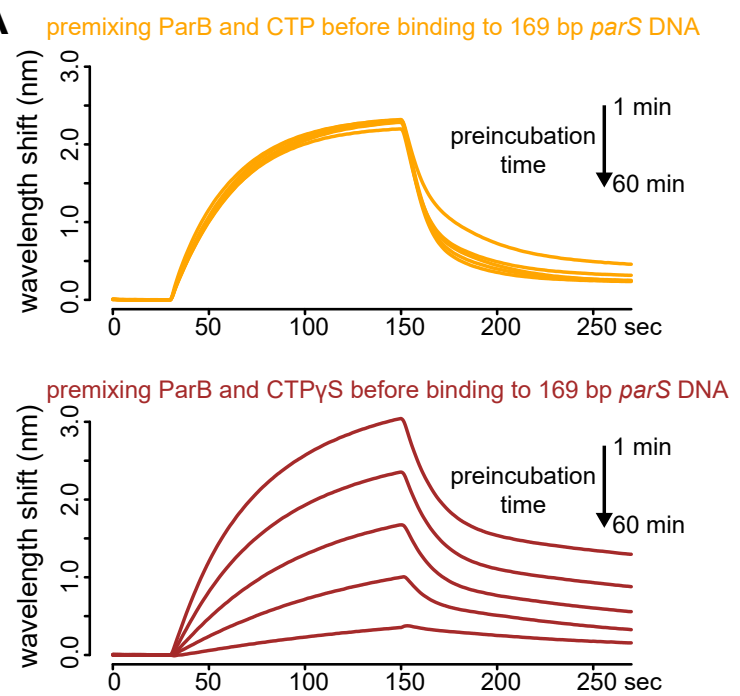

B

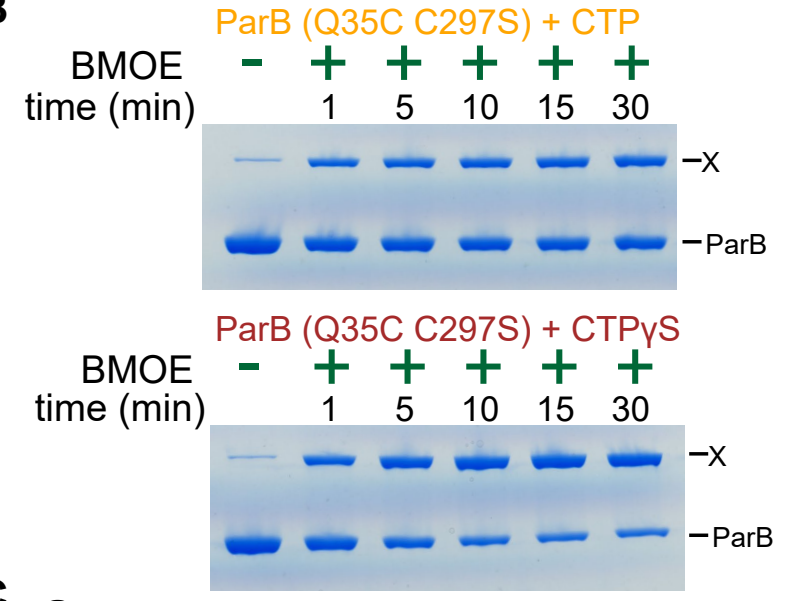

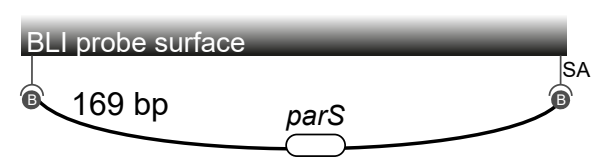

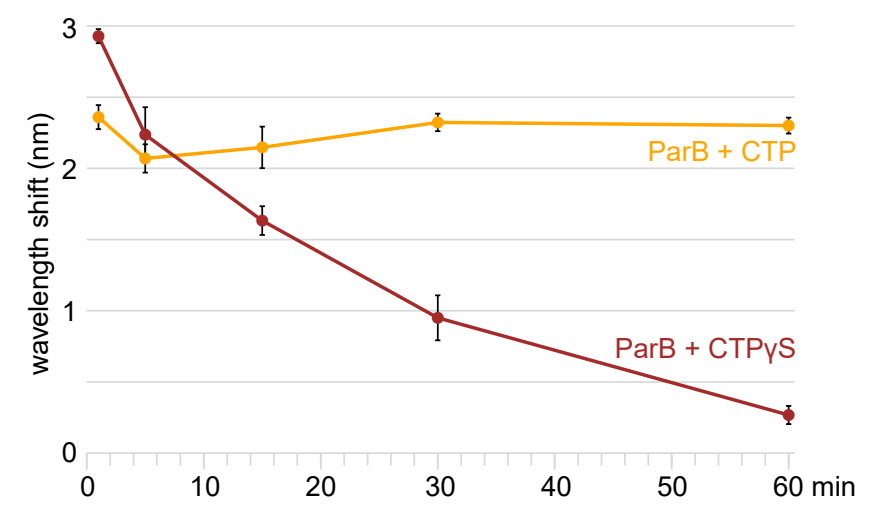

100

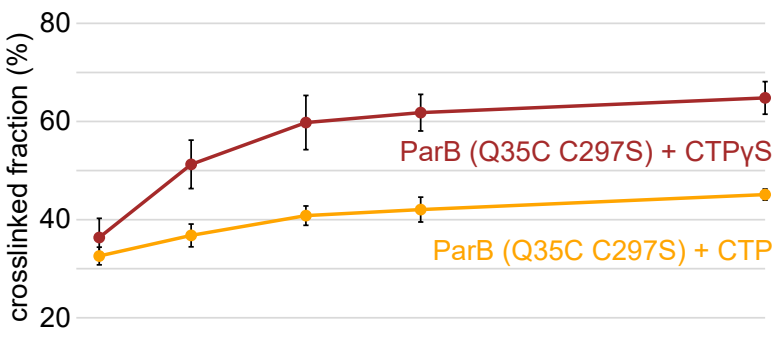

0

10

15

20

25

$30 \min$

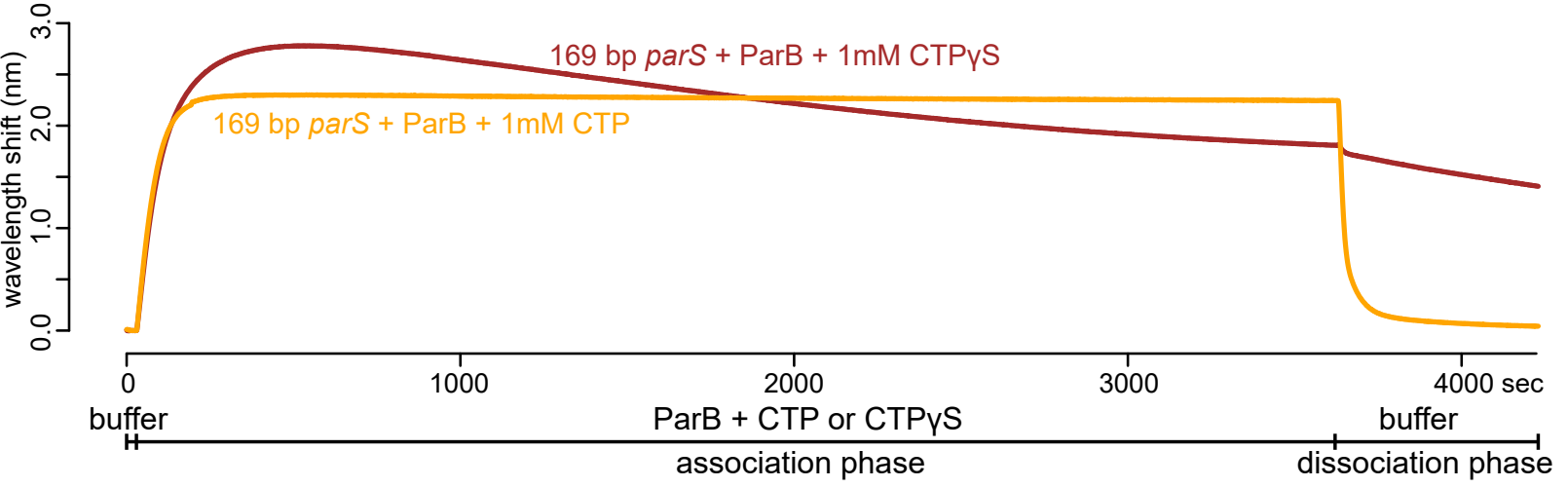

Figure 6. ParB accumulation on DNA is unstable in the presence of a non-hydrolyzable analog CTPYS. (A) (Left panel) BLI analysis of the interaction between a premix of $1 \mu \mathrm{M}$ Caulobacter ParB$\mathrm{His}_{6} \pm 1 \mathrm{mM}$ CTP or CTPYS and a 169-bp dual biotin-labeled parS DNA. Purified ParB was preincubated with CTP or CTPYS for 1, 5, 15, 30, or 60 min before BLI analysis. (Right panel) Quantification of ParBDNA interaction at the end of each association phase $\left(150^{\text {th }} \mathrm{sec}\right)$. Error bars represent SD from three replicates. (B) (Left panel) Time course of Caulobacter ParB (Q35C C297S) cross-linking with CTP or CTPyS in the absence of parS DNA. Purified ParB-His ${ }_{6}$ (Q35C C297S) $(10 \mu \mathrm{M})$ were preincubated with $1 \mathrm{mM}$ CTP or CTPYS for 1, 5, 10, 15, or 30 min before BMOE was added. $X$ indicates a cross-linked form of ParB. (Right panel) Quantification of the cross-linked (X) fractions. Error bars represent SD from three replicates. (C) BLI analysis of the interaction between a premix of $1 \mu \mathrm{M}$ Caulobacter ParB$\mathrm{His}_{6} \pm 1 \mathrm{mM}$ CTP or CTPYS and a 169-bp dual biotin-labeled parS DNA. CTP or CTPYS was added to purified ParB, and the mixture was immediately used for BLI experiments. All buffers used for experiments in this figure contained $\mathrm{Mg}^{2+}$. 


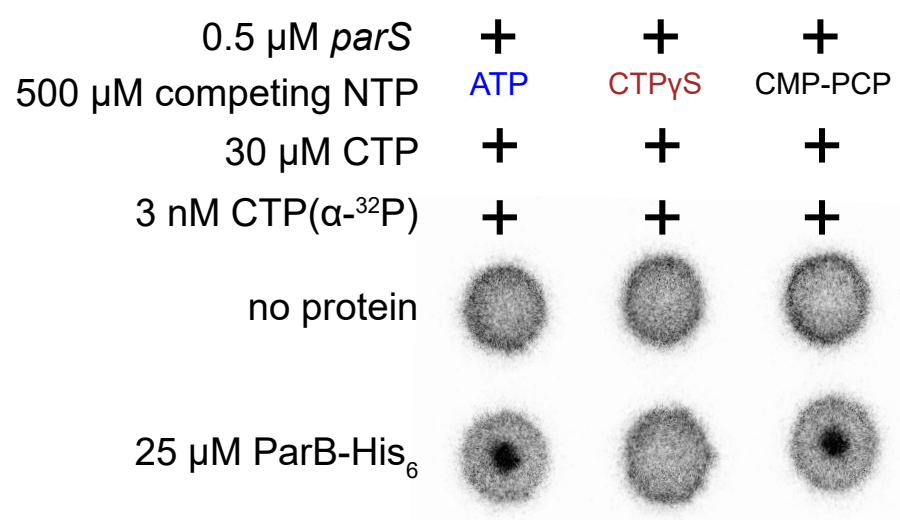

Figure 6-figure supplement 1. Caulobacter ParB binds CTP and a non-hydrolyzable analog CTPYS but not CMP-PCP. CTPYS (but not CMP-PCP) outcompeted radioactive CTP $\alpha-P^{32}$ for binding to ParB-parS complex, indicating that Caulobacter ParB can bind to CTPYS. Binding to radioactive CTP $\alpha-P^{32}$ was monitored by DRaCALA assay. The bulls-eye staining indicates CTP binding due to a more rapid immobilization of protein-ligand complexes compared to free ligands alone. 
A

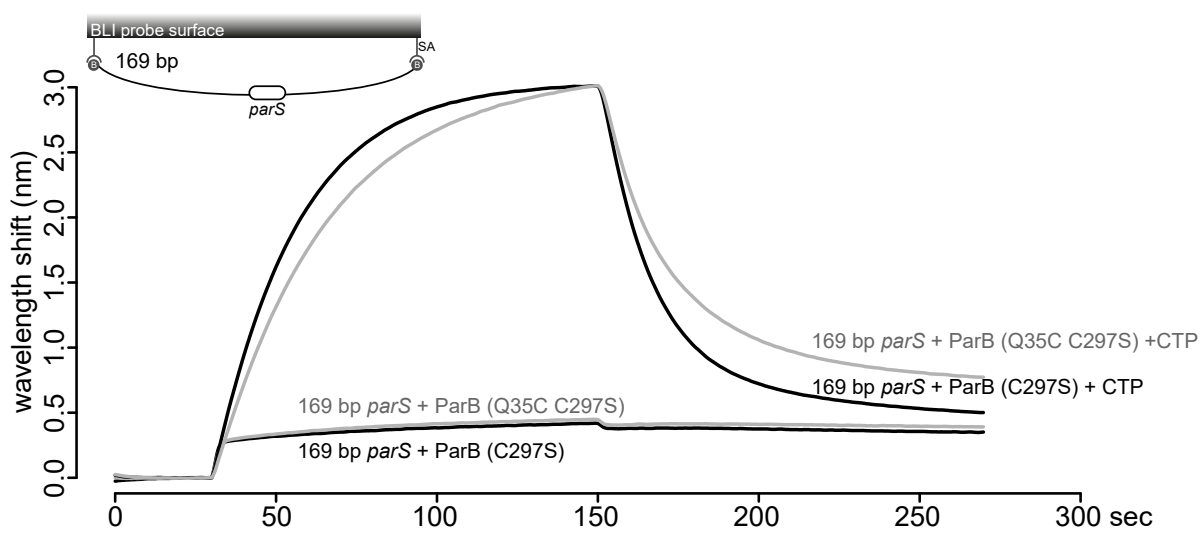

B CcParB ЮC297S-

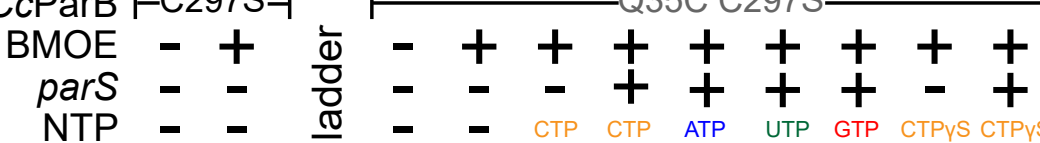
NTP
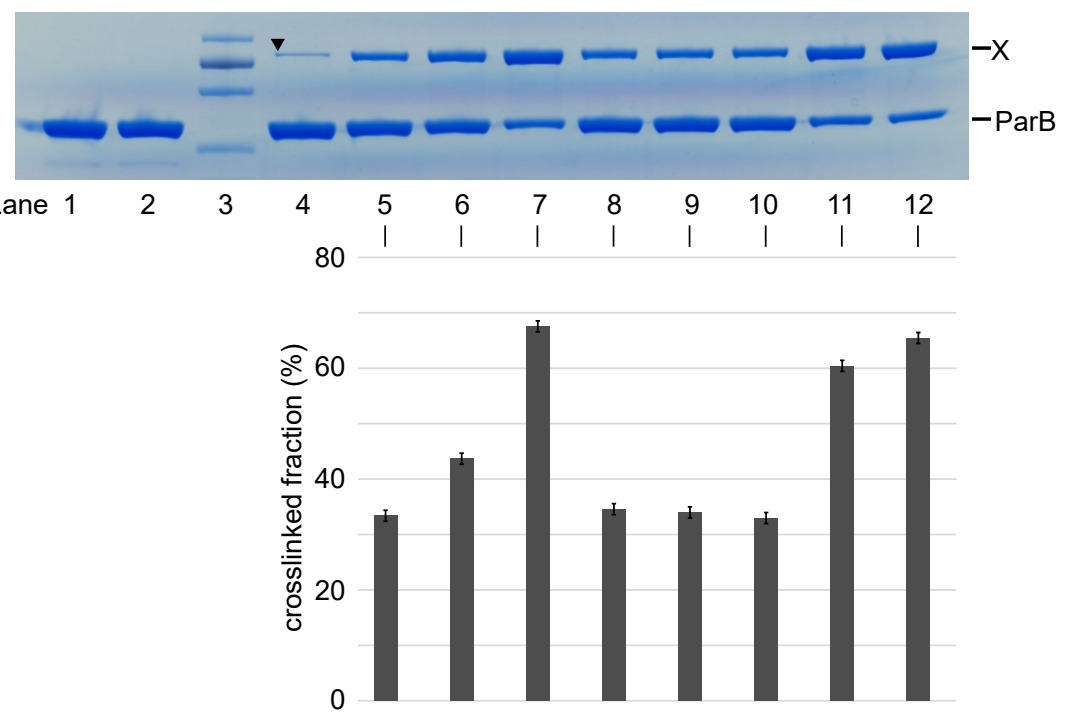

Figure 6-figure supplement 2. BLI analysis and gel analysis of cross-linking products of purified Caulobacter ParB (Q35C C297S). (A) BLI analysis of the interaction between a premix of $1 \mu \mathrm{M}$ Histagged ParB (C97S) or (Q35C C297S) $\pm 1 \mathrm{mM}$ CTP and a 169-bp dual biotin-labeled parS DNA. In the presence of CTP, both variants of ParB were able to spread, indicating that the engineered mutations Q35C and C297S did not impair the function of ParB in vitro. (B) Purified Caulobacter ParB-His 6 (Q35C C297S) \pm NTPs \pm parS DNA were incubated for $15 \mathrm{~min}$ at room temperature before cross-linking with BMOE. A cysteine-less ParB (C297S) was used as a negative control. X indicates a cross-linked form of ParB. A solid black triangle on lane 4 indicates a contaminated protein from the purification of ParB$\mathrm{His}_{6}$ (Q35C C297S). A lower panel shows the quantification of the cross-linked (X) fractions. Error bars represent SD from three replicates. 
A Nucleation

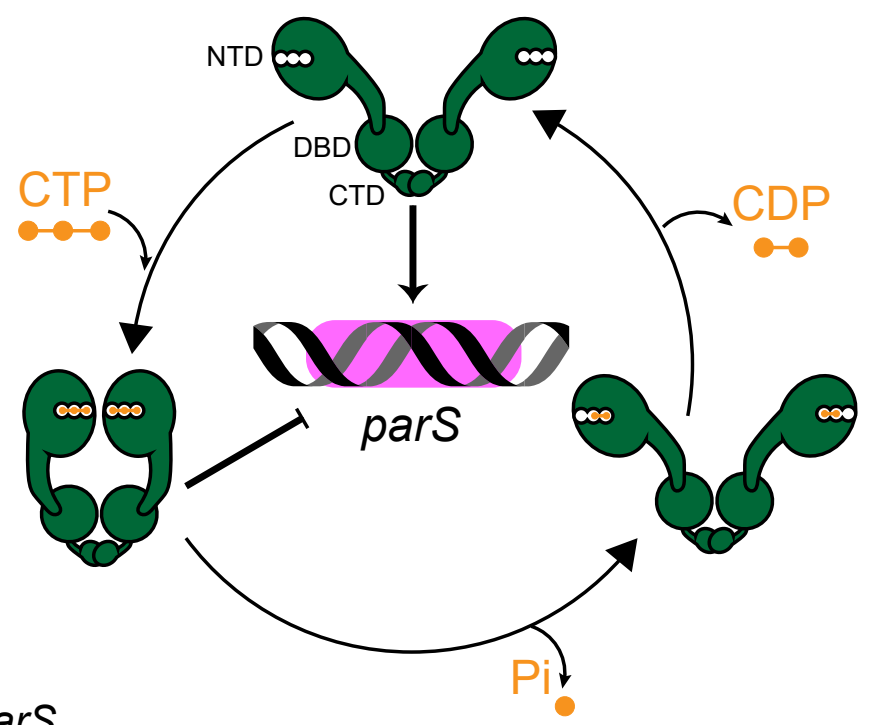

B Escape from parS

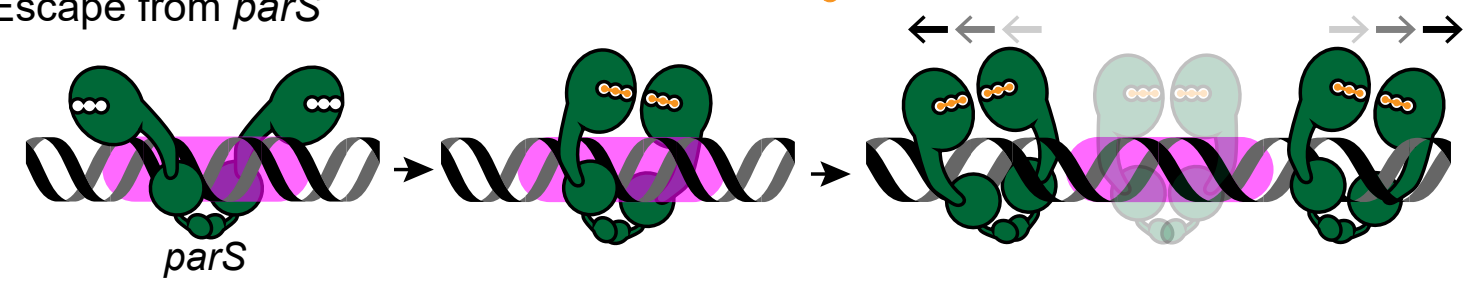

C Spreading and bridging

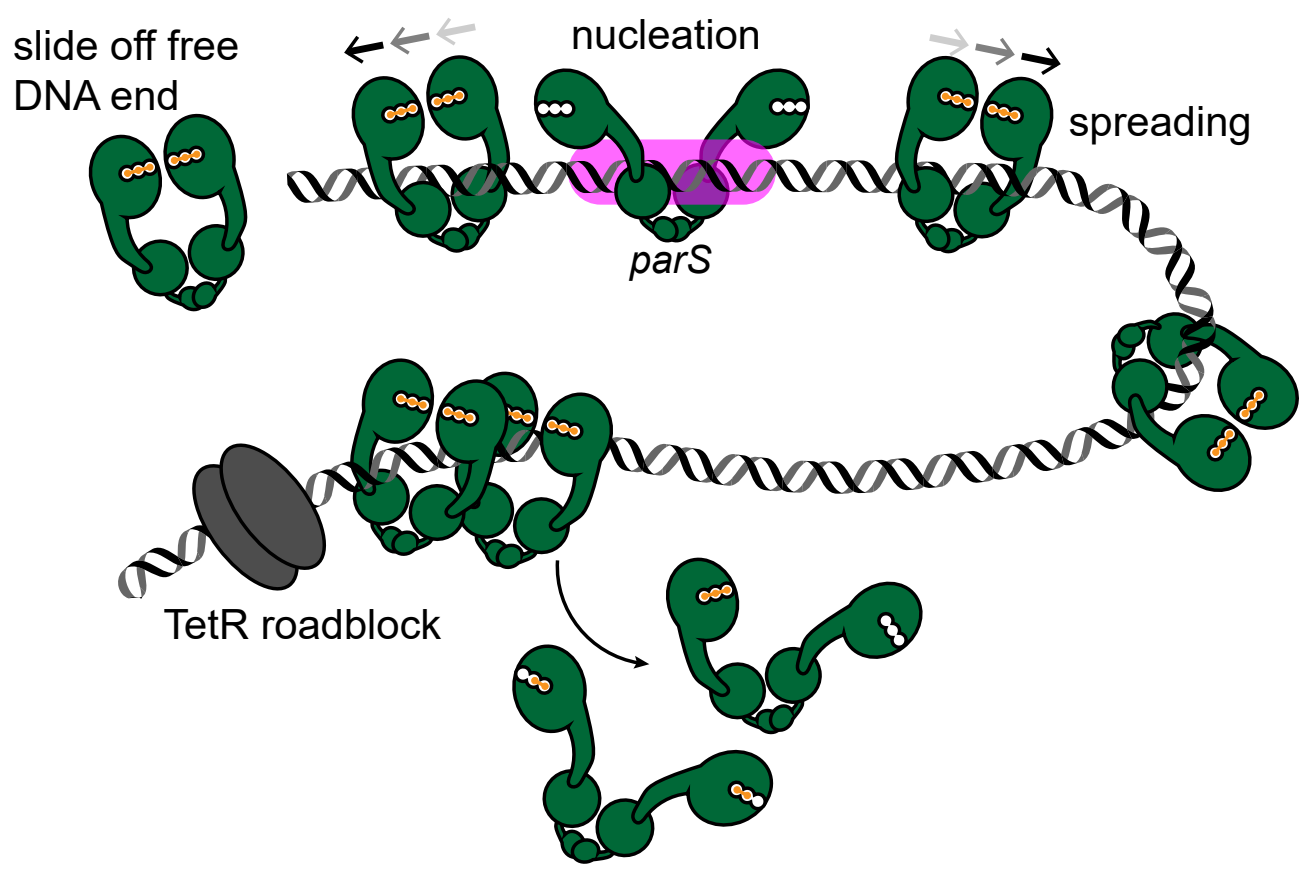

Figure 7. A model for Caulobacter ParB nucleation and spreading. (A) Caulobacter ParB nucleation at parS. CTP (orange) reduces Caulobacter ParB (dark green) nucleation at parS (magenta box), presumably by inducing conformational changes that are incompatible with a site-specific parS binding (Soh et al., 2019). Only apo- or CDP-bound ParB can nucleate on parS. ParB hydrolyzes CTP at a faster rate in the presence of parS. The domain architecture of ParB is also shown: NTD: N-terminal domain, DBD: DNA-binding domain, and CTD: C-terminal domain. (B) Caulobacter ParB escapes from the nucleation site parS. Apo-ParB at parS binds CTP and slides laterally away from the nucleation site parS while still associating with DNA. (C) Caulobacter ParB sliding and spreading on DNA. CTP-bound ParBs diffuse from the nucleation site parS and can run off the free DNA end unless they are blocked by DNA-bound roadblocks such as transcriptional regulators e.g. TetR. CTP hydrolysis is not required for ParB to escape from the nucleation parS site but might contribute to ParB recycling. It is not yet known whether both CTP molecules on a ParB dimer are concertedly hydrolyzed/dissociated for ParB to escape from the chromosome or a heterodimer state of ParB with a single CTP bound also exists in vivo. 